\title{
Modularity in Contracts: Boilerplate and Information Flow
}

\section{Citation}

Henry E. Smith, Modularity in Contracts: Boilerplate and Information Flow, 104 University of Michigan Law Review 1175 (2006).

\section{Permanent link}

http://nrs.harvard.edu/urn-3:HUL.InstRepos:8789604

\section{Terms of Use}

This article was downloaded from Harvard University's DASH repository, and is made available under the terms and conditions applicable to Other Posted Material, as set forth at http:// nrs.harvard.edu/urn-3:HUL.InstRepos:dash.current.terms-of-use\#LAA

\section{Share Your Story}

The Harvard community has made this article openly available.

Please share how this access benefits you. Submit a story.

\section{Accessibility}




\title{
MODULARITY IN CONTRACTS: BOILERPLATE AND INFORMATION FLOW
}

\author{
Henry E. Smith* \\ TABle of CONTENTS
}

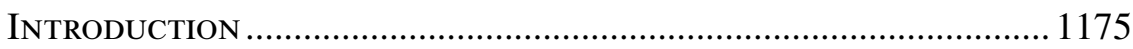

I. ModUlarity IN CONTRACT ……....................................... 1179

A. Modularity and Complexity ............................................ 1180

B. Modular Boilerplate ......................................................... 1191

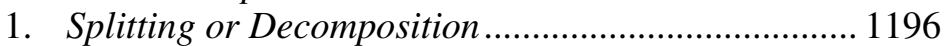

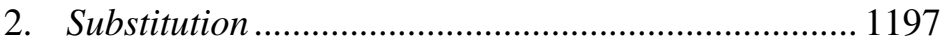

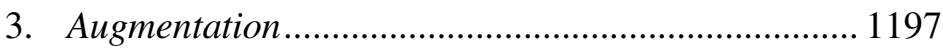

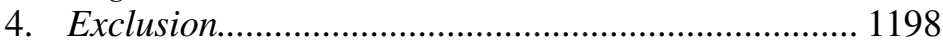

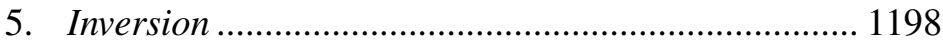

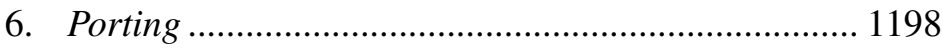

II. A Model of Modularity in Contract Boilerplate...... 1203

A. Formalism and Context-Dependence .............................. 1203

B. An Information-Theoretic Model of Boilerplate............... 1207

III. FURTHER APPLICATIONS ...................................................... 1214

A. Nonmodularity in Legal Realism................................... 1214

B. Comparative Contracts and the Seams

in the Web of Law .............................................................. 1219

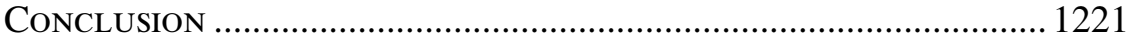

\section{INTRODUCTION}

Contractual boilerplate is a little like property. Such a statement might seem like a category mistake. After all, contractual boilerplate language is part of contracts, which, unlike property, are freely customizable by the parties. Contracts create rights between those parties, not against the world at large. Nor do people who devise new boilerplate terms usually have intellectual property in the provisions themselves.

I will argue that, in an interesting and overlooked way, boilerplate is the first way station on the road from contract to property. In particular, boilerplate, like all legal communication, is the result of striking a trade-off between communicating intensively in a narrow sphere or communicating in

\footnotetext{
* Professor of Law and Cognitive Science, Yale Law School. A.B. 1986, Harvard; A.M. (German) 1987, Ph.D. (Linguistics) 1992, Stanford; J.D. 1996, Yale. -Ed. For comments and discussions, I would like to thank James Grimmelmann, Jim Lindgren, Tom Merrill, Jonathan Nash, George Triantis, and participants at workshops at Berkeley, Columbia, Northwestern, and the Symposium on "Boilerplate": Foundations of Market Contracts at the University of Michigan Law School. All errors are mine.
} 
a more stripped-down formal way in a wider variety of contexts. ${ }^{1}$ Contract and property form something close to corner solutions here. Contracting parties are allowed to be as idiosyncratic as they like, but the idiosyncrasies apply simply to their own dealings - usually not to those of third parties. ${ }^{2}$ At the other end of the spectrum, property law deals in simple stable signals with a wide currency, but the rules of property eschew a lot of contextual detail. This makes property rights easy to adapt to many contexts and allows those whose expertise is minimal to avoid running afoul of these in rem rights. The simplicity of property rights also helps potential purchasers to inform themselves about the rights in the process of acquiring them. ${ }^{3}$

Boilerplate language in contracts is somewhere in the middle of this spectrum running from information-rich contract rights limited to a particular deal to simple standardized property rights availing against "the world." Once this aspect of boilerplate is understood, an information-cost theory of property can shed light on how boilerplate is-and is not-used in contracts. By definition boilerplate is meant to be used in more than one contract, and boilerplate is more self-contained and less specific to a particular contract than might be expected from contract theory. ${ }^{4}$ Boilerplate is highly standardized, and when courts interpret boilerplate they treat it as intentionally standardized and not harboring unusual meanings. In other words, some portability of boilerplate is achieved at the price of tailoring such provisions to particular contexts.

In striking this trade-off between tailoring and portability, boilerplate takes advantage of modularity. In general, modularity is a device to deal with complexity by decomposing a complex system into pieces (modules), in which communications (or other interdependencies) are intense within the module but sparse and standardized across modules. Two elements are more likely to be in the same module if they are part of a dense web of connections, whereas they are more likely to be part of separate modules if they are weakly connected in this sense. Modularity is thus a matter of degree. For example, in a computer program, an initial version might have some kind of a print function embedded in various parts of the program. Instead,

1. For development of this theory where context is defined by audience type, see Henry E. Smith, The Language of Property: Form, Context, and Audience, 55 Stan. L. Rev. 1105, 1125-28 (2003).

2. And when they do, the law tends to treat these third-party aspects of contracts in a more formal standardized fashion than in contract law more generally. See id. at 1177-90.

3. Information costs include but are not limited to verification costs. See Thomas W. Merrill \& Henry E. Smith, Optimal Standardization in the Law of Property: The Numerus Clausus Principle, 110 YALE L.J. 1, 30 n.117, 32-33, 43-51 (2000); Smith, supra note 1, at 1125-26 (discussing types of information and information cost); see also Benito Arruñada, Property Enforcement as Organized Consent, 19 J.L. ECON. \& ORG. 401 (2003) (analyzing role of verification costs in organizing property system); Henry Hansmann \& Reinier Kraakman, Property, Contract, and Verification: The Numerus Clausus Problem and the Divisibility of Rights, 31 J. Legal Stud. S373 (2002) (elaborating consequences of verification costs for a system of property rights).

4. Contract theory posits a complete contract covering every verifiable contingency as a benchmark, and the puzzle is why actual contracts fall far short of this ideal. Karen Eggleston, Eric A. Posner \& Richard Zeckhauser, The Design and Interpretation of Contracts: Why Complexity Matters, 95 Nw. U. L. Rev. 91 (2000). 
one can create a print module that can be called upon by other parts of the program in standardized ways. When revisions are being made to the print module or to the rest of the program the interdependencies (which I will also call "interactions") are much easier to foresee. If a better print module comes along it can be substituted for the existing one, or the success of the print module at hand can lead to its adoption in a wide variety of other programs. With the rise of object-oriented programming this style of software design has gained widespread use.

Modularity carries with it characteristic costs and benefits. Modularity is beneficial in that it makes complexity manageable. It also allows multiple people to work on a larger problem, often in very specialized ways, without incurring the costs of intense communication. Finally, modularity allows a system to manage uncertainty; because each module can function and develop in relative isolation, these processes can occur without the need to resolve uncertainty elsewhere in the system. In this sense modularity is said to create options. Without modularity, keeping the options for certain decisions open would be prohibitively costly. Modularity achieves these benefits by interrupting information flow, through what is often called "information hiding"; only certain kinds of information can be passed from module to module, reducing the need to know what's going on in the other black boxes. As long as the design rules built into the interface are obeyed, changes will not have costly ramifications elsewhere.

Although modularity is increasingly employed in areas ranging from biological evolution to organizational design, some of the most dramatic examples of the power of modularity and much of our understanding of its implications come from the realm of computer hardware and software. A key turning point in computer design came with the IBM System/360, introduced in 1964, which was the first truly modular computer design. ${ }^{5}$ Nonmodular design that had prevailed before the mid-1960s had become much too cumbersome. Similarly in software, the rise of the UNIX operating system began a similar harnessing of modularity, and more recently the role of modularity in open-source software like Linux is well-known. ${ }^{6}$ Most relevantly for our purposes, the development of object-oriented programming (with the rise of languages like Smalltalk, Java, and C++) allowed all sorts of computer programs to be more thoroughly modular. When programs become very complex, breaking a problem down by modules rather than by flow chart can be key to managing complexity and allowing for flexibility in evolution. In this Article, I will draw an analogy between writing contracts and writing computer programs.

5. See, e.g., 1 Carliss Y. Baldwin \& Kim B. Clatk, Design Rules 6-11, 169-94 (2000).

6. See, e.g., Yochai Benkler, Coase's Penguin, or, Linux and The Nature of the Firm, 112 Yale L.J. 369 (2002); Greg R. Vetter, The Collaborative Integrity of Open-Source Software, 2004 UTAH L. Rev. 563.

7. See, e.g., Grady Booch, Object-Oriented Analysis and Design (2d ed. 1994); Edward Yourdon, Object-Oriented Systems Design: An Integrated Approach (1994). 
The role of modularity in boilerplate has been largely overlooked in law and economics, for reasons having their roots deep in the Coasean tradition. As Tom Merrill and I have argued elsewhere, Coase assumed a hyperrealist view of property which bears little relation to the traditional notion of property as a right to exclude from a thing, good against the world. ${ }^{8}$ Instead, Coase, like the legal realists before him, tended to emphasize use-rights, which in Coase's case would be the product of enlightened judges making economically informed decisions about resource conflicts where parties cannot bargain to the efficient result themselves. ${ }^{9}$ One would naturally expect such solutions to be finely tailored, and they would have little reason to track traditional exclusion rights. In a moment of extreme candor in the course of his discussion of spectrum rights, Coase even expresses his view that the concept of property "tends to obscure the question that is being decided" that "whether we have the right to shoot over another man's land has been thought of as depending on who owns the airspace over the land. It would be simpler to discuss what we should be allowed to do with a gun." "

The importance of modularity has been easy to overlook in traditional law and economics. First, the lumpy character of entitlements and their ability to encapsulate and hide information does not figure in theories at all. Instead, in law and economics more information is usually considered better. Exceptions to the more-is-better approach, such as the potential for information overload, are not generally considered problems in the theory of entitlements anyway. ${ }^{12}$ Second, traditional law and economics would not be very compatible with modularity because legal concepts and formalism implement the principle of modularity, but law and economics inherits the anticonceptualism and antiformalism of the legal realists. I argue that formalism properly understood is simply one way of striking the inevitable informational trade-off between intense communication in a narrow range of contexts and more standardized - formal - ways of communicating more widely. Finally, law and economics, even behavioral law and economics, does not emphasize the benefits of modularity for human comprehension and innovation, even though pioneering behavioral economist Herbert Simon considered the very notion of bounded rationality to imply a strong trend towards modularity in human problem solving and institution build-

8. Thomas W. Merrill \& Henry E. Smith, What Happened to Property in Law and Economics?, 111 YALE L.J. 357 (2001).

9. R.H. Coase, The Problem of Social Cost, 3 J.L. \& Econ. 1, 19 (1960) (“"[T]he courts should understand the economic consequences of their decisions and should, insofar as this is possible without creating too much uncertainty about the legal position itself, take these consequences into account when making their decisions.").

10. R.H. Coase, The Federal Communications Commission, 2 J.L. \& Econ. 1, 34 (1959).

11. Id.

12. See, e.g., Wesley A. Magat \& W. Kip Viscusi, Informational Approaches to REgUlATION 90-105 (1992) (summarizing controversy and presenting study); Richard Craswell, Interpreting Deceptive Advertising, 65 B.U. L. REv. 657, 690-91 (1985) (noting controversy over information overload theory under which more information can cause recipients to ignore all information, but noting possible crowding-out effect of mandatory information). 
ing. ${ }^{13}$ As has proved true in cognitive science, a complex phenomenon can be more amenable to study if the phenomenon itself is modular, as most cognitive scientists now consider the human mind to be. ${ }^{14}$ Likewise, computer programmers are well aware that human minds deal with complexity much better if problems are broken down in a modular way. For this reason alone, modularity makes for good programming style. Furthermore, evolution-even evolution not directed by a central intelligence-often gravitates towards modular systems because of their ability to adapt to new conditions. ${ }^{15}$

If so, the evolution of contract law and of privately circulating forms of boilerplate can be explained as the product of a similar evolutionary logic.

In the next Part, I will introduce the notion of modularity and demonstrate that it plays a pervasive role in managing contractual complexity, particularly through its use in boilerplate provisions. In Part II, the Article turns to a simple model of modularity in which such formal devices reflect a trade-off between the information-intensiveness and context-dependence of communication and its adaptability to a wide variety of contexts. Contractual boilerplate falls between highly tailored contractual provisions and standardized property rights in that contractual boilerplate presents externalities that stem from the lack of fit between language used and contexts that the drafter will not fully take into account. The information-cost theory helps explain the mild modularity of contracts and why the devices used to manage contractual complexity are reminiscent of those in property law but much less draconian. Boilerplate calls for a more formal and less holistic style of interpretation than do other provisions of contracts. The theory also reinforces and refines the view that contract reading costs contribute to their simplicity. Part III then turns to indirect evidence for the information-cost theory from the limits of the legal realist approach to contracts and the wellknown shortness of German contracts relative to their U.S. "counterparts." The Article concludes with some thoughts on why modularity calls into question some time-worn views of law as a "seamless web."

\section{Modularity IN CONTRACT}

Modularity is a method of dealing with complexity, and I will argue that boilerplate plays a crucial role in bringing the advantages of modularity to contracts. In this Part, I sketch out the nature of modular systems and how

13. Herbert A. Simon, The Sciences of the Artificial (2d ed. 1981).

14. The landmark study is Jerry A. Fodor, The Modularity of Mind (1983). Although I am not claiming that there is any one-to-one mapping between modules we can identify in the law of contracts or in contracts themselves and the modularity of the human mind, there are reasons to think that there is some relation.

15. See, e.g., Modularity in Development and Evolution (Gerhard Schlosser \& Günter P. Wagner eds., 2004); Lauren W. Ancel \& Walter Fontana, Plasticity, Evolvability, and Modularity in RNA, 288 J. Experimental Zoology 242 (2000); Günter P. Wagner \& Lee Altenberg, Complex Adaptations and the Evolution of Evolvability, 50 Evolution 967 (1996); John J. Welch \& David Waxman, Modularity and the Cost of Complexity, 57 Evolution 1723 (2003). 
they deal with complexity, both static and dynamic. With this background in hand, the modularity of boilerplate becomes one of its most striking features.

\section{A. Modularity and Complexity}

Modularity is a key device for dealing with complexity, and understanding modularity presupposes a theory, or at least a definition, of complexity. This has been famously difficult both as a matter of general theory and as applied to the law. ${ }^{16}$ Nevertheless, for our purposes it is useful to go back to an informal definition of a complex system proposed by Herbert Simon, whose theory of bounded rationality forms the foundation of modern behavioral decision theory. ${ }^{17}$ At first approximation, a complex system is one characterized by a large number of internal interactions, or, in Simon's words:

one made up of a large number of parts that interact in a nonsimple way. In such systems the whole is more than the sum of its parts, not in an ultimate, metaphysical sense but in the important pragmatic sense that, given the properties of the parts and the laws of their interaction, it is not a trivial matter to infer the properties of the whole. ${ }^{18}$

Modularity allows complexity to become manageable by interrupting information flow within the system. Forming a modular system involves partially closing off some parts of the system and allowing these encapsulated components to interconnect only in certain ways. This allows work to go on in parallel and facilitates certain kinds of innovation and evolution for a simple reason: adjustment can happen within modules without causing major ripple effects. More sweeping change can call for remodularization, but much can be accomplished without altering the modular setup. Crucially, human understanding of any system is enhanced by breaking it up ("decomposing" it) into modules. Simon offers a little parable to illustrate the benefits of modularity:

There once were two watchmakers, named Hora and Tempus, who manufactured very fine watches. Both of them were highly regarded, and the phones in their workshops rang frequently-new customers were constantly calling them. However, Hora prospered, while Tempus became poorer and poorer and finally lost his shop. What was the reason?

The watches the men made consisted of about 1,000 parts each. Tempus had so constructed his that if he had one partly assembled and had to put it

16. See, e.g., Richard A. Epstein, Simple Rules for a Complex World 21, 28 (1995) ("The proper response to more complex societies should be an ever greater reliance on simple legal rules ....."); Eric Kades, The Laws of Complexity and the Complexity of Laws: The Computational Complexity Theory for the Law, 49 Rutgers L. Rev. 403, 449 (1997); Louis Kaplow, A Model of the Optimal Complexity of Legal Rules, 11 J.L. Econ. \& ORg. 150 (1995); Peter H. Schuck, Legal Complexity: Some Causes, Consequences, and Cures, 42 DuKE L.J. 1 (1992).

17. Herbert A. Simon, Models of Bounded Rationality (1982); Herbert A. Simon, Models of Man: Social and Rational (1957); Simon, supra note 13.

18. Simon, supra note 13, at 195. 
down - to answer the phone, say - it immediately fell to pieces and had to be reassembled from the elements. The better the customers liked his watches, the more they phoned him and the more difficult it became for him to find enough uninterrupted time to finish a watch.

The watches that Hora made were no less complex than those of Tempus. But he had designed them so that he could put together subassemblies of about ten elements each. Ten of these subassemblies, again, could be put together into a larger subassembly; and a system of ten of the latter subassemblies constituted the whole watch. Hence, when Hora had to put down a partly assembled watch to answer the phone, he lost only a small part of his work, and he assembled his watches in only a fraction of the man-hours it took Tempus. ${ }^{19}$

Simon goes on to show that if the probability of being interrupted while a part is being added to an incomplete assembly is $p$, then each interruption costs on average the time to assemble $1 / p$ parts, and the probability that Tempus will finish is $(1-p)^{1000}$, which is very small for $p$ greater than $.001{ }^{20}$ If $p$ is about .01, then Tempus will take on average 4000 times as long as Hora. ${ }^{21}$ The modular structure of Hora's watches insulates many parts of the watch from the damage of an interruption.

In software, modular structure can make the program being developed more understandable to overall coordinators, at least in broad outline. Those working on various parts need not worry about what others working on other modules are doing, other than being assured that those modules will fit in certain stereotyped ways into the overall structure. This allows work to go on in parallel, and a team can develop software that no one mind could comprehend in all its details.

Modularity also benefits groups of many kinds working together. A burgeoning literature seeks to explain the modular structure of organizations, especially those in the computer industry, as a result of the modular structure of the products they produce. ${ }^{22}$ A dramatic example of the costs of nonmodularity comes from the development of OS/360, the operating system for the IBM 360 line of computers. ${ }^{23}$ Although the 360 itself was modular, the manager of the software project, Frederick Brooks, took a nonmodular approach and insisted on attention to interdependencies without restriction. Those working on all the various tasks had to keep abreast of developments by all the others and inform them about all of their own work. The result was a nightmare. Within six weeks the central log in which all

19. Id. at 200 .

20. Id. at 201 .

21. Id.

22. See, e.g., Baldwin \& Clark, supra note 5; Managing in the Modular Age: Architectures, Networks and Organizations (Raghu Garud, Arun Kumaraswamy \& Richard N. Langlois eds., 2003); Richard N. Langlois, Modularity in Technology and Organization, 49 J. Econ. BeHAV. \& ORG. 19 (2002).

23. BALDWIN \& CLARK, supra note 5, at 6-11, 169-94; Langlois, supra note 22. 
this information was kept grew to be five feet thick, and growing at 150 interfiled pages a day. ${ }^{24}$ Brooks concluded that past a certain point in adding workers, the communications costs of a nomodular approach even exceed the benefits of a division of labor. ${ }^{25}$

Consider an organization with ten people. The question is which of the following organizations is more complex and why-an organization in which everyone is connected to everyone, a strictly hierarchical one, a collegial hierarchy, or a partial hierarchy, as depicted in these graphs: ${ }^{26}$

\section{FIGURE I}

\section{EQUAL PARTNERS/COMPlete GRAPH}

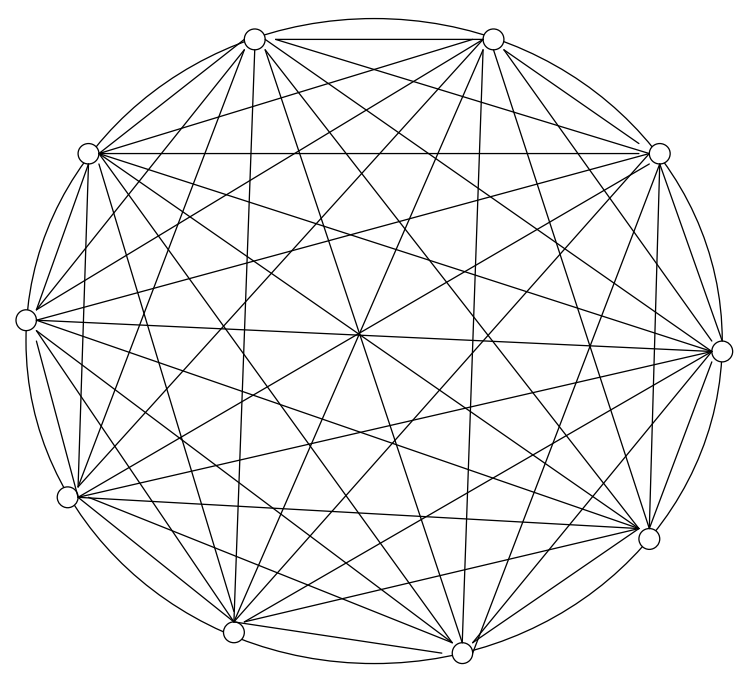

24. Frederick P. Brooks, The Mythical Man-Month: Essays on Software EngineerING $76(1975)$.

25. Id. at 18-19.

26. See, e.g., Raymond Greenlaw \& H. James Hoover, Fundamentals of the Theory of Computation: Principles and Practice 287-313 (1998). For an application of graph theory to hierarchies in business organization, see Robert Charles Clark, Corporate LaW 801-16 (1986). 
FIGURE 2

(Strict) Branching Hierarchy

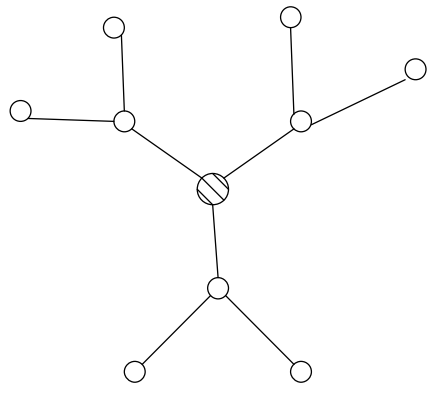

or

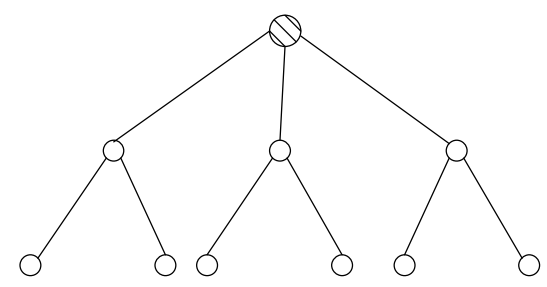

FIGURE 3

Branching Collegial Hierarchy

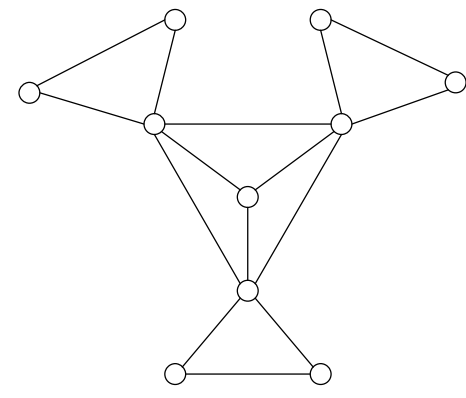

FIGURE 4

Partial Hierarchy

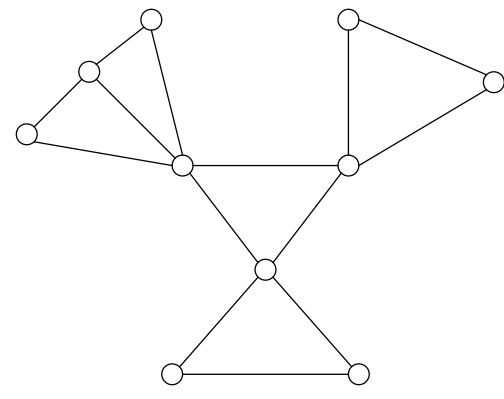

Only the graphs in Figures 2 through 4 are modular. Two nodes are likely to be in the same module if they are part of a web of mutual connections, as opposed to the weaker connections of these nodes to nodes outside the module. The more this is so, the more likely a candidate such a group of 
nodes is to be a module. In the graphs in Figures 3 and 4, the contrast of communication within the groups of three versus the constricted communication, here through one member only, with the outside is striking. By contrast, the first graph (called a complete graph because it has all the possible links between the nodes) is not modular at all. In Figure 4 there is no chief executive but a partial hierarchy with three modules, two containing three nodes (persons if this depicts an organization) and one with four nodes. It could also be the case that some of the links are more important than others, which in graph theory is represented by associating a number with the link between two nodes. One rough measure of complexity is the number of links per node, as illustrated in the following table:

Links/Nodes

(1) Equal partners/Complete Graph

$45 / 10=4.5$

(2) (Strict) Branching Hierarchy

(3) Branching Collegial Hierarchy

$9 / 10=0.9$

(4) Partial Hierarchy

$15 / 10=1.5$

$12 / 9=1.33$

More generally, for the complete graph the number of links is $n(n-1) / 2$, which increases much faster than in the case of the strict branching hierarchy (which does not increase at all but sacrifices a lot of potentially useful horizontal links), and the two hybrids, the branching collegial hierarchy and the partial hierarchy, which are in between. This suggests a connection as well to computational complexity theory, the study of the minimum running time for programs to solve various problems. ${ }^{27}$ Some simple-sounding problems are provably intractable, and many are in a class that is probably intractable. ${ }^{28}$ For example, the Traveling Salesman Problem sounds simple: calculate the shortest route such that starting from a given city one visits each city once before returning home. For three cities besides the home city the number of choices is $3 !=3 \times 2 \times 1=6$; for 10 cities it is $10 !=$ $3,628,800$. The problem is that $n$ ! increases exponentially, and the general problem is probably not computable except by approximation. ${ }^{29}$

In the example given in the above Figures, the organization with connections everywhere seems simple, but consider that communication and coalitions could involve any subset of the people here; enumerating the subsets of a set is intractable because the time it takes increases exponentially

27. See, e.g., Michael R. Garey \& David S. Johnson, Computers and Intractability: A Guide to the Theory of NP-Completeness (1979); Greenlaw \& Hoover, supra note 26. For an application of computational complexity theory to law, see Kades, supra note 16.

28. I am referring to the class of problems called NP-complete (nondeterministic polynomial complete, or computable in polynomial time using a random choice of solutions with complete luck), which are considered probably intractable (although proving this is one of the great unsolved problems). See GreEnlaw \& Hoover, supra note 26, at 287-313. For an informal introduction, see Keith Devlin, The Millennium Problems: The Seven Greatest Unsolved Mathematical PuZZles of Our Time 105-30 (2002).

29. The Traveling Salesman Problem is NP-complete. See, e.g., Devlin, supra note 28, at $112-18,121-28$. 
with the size of the set. ${ }^{30}$ The other organizations are modular in that within modules there is intense communication, but these modules are only weakly connected to other modules. In the hierarchical system these connections are the vertical information channels.

The diagrams above can also be interpreted in other ways. For example, the nodes could denote uses of an asset that could be the subject of property rights. If so, one of the problems in deploying the asset is to decide which combination of uses is best. In general the number of combinations is $n ! /((n-r) ! r !)$ for a set of $n$ uses taken $r$ at a time. Indeed, we may not know ex ante how many of the uses are compatible with which one and which those are. It may be that some uses are compatible if sequenced properly, in which case the number of permutations (ordered combinations) is even greater, that is, $n ! /(n-r)$ !. Moreover, as outside observers we may not know the exact makeup of the set. One way to handle this type of situation is to delegate the choice of many of these uses to owners who then interact with each other and the state in certain standardized ways, as we actually do in the law of property. ${ }^{31}$

To do this we might divide the world up into assets based on natural lines of decomposition and specify modularity between the resulting rights. An asset should embrace known complementary attributes, but we can avoid specifying them directly, by hiding them behind a simple right to exclude. ${ }^{32}$ If A owns Blackacre, this means that A has the right to exclude unspecified others from a given space or object (real or personal property). Dutyholders likewise need not know much about the owner or the internal set of uses but only to stay off and not to commit various kinds of invasions. ${ }^{33}$ Exclusion rights implement the "information hiding" or encapsulation that is the hallmark of modularity. As I have argued elsewhere, the law is strikingly stubborn about sticking with this exclusion strategy and only in exceptional circumstances moves in the direction of direct balancing of uses. ${ }^{34}$ Indeed, despite the best efforts of academics and Restatement authors, the law of nuisance surprisingly still affords a major role for the seemingly very arbitrary requirements of an invasion (by odors, vibrations, et cetera), which can

30. That is, enumerating the subsets of a given set requires exponential time. See, e.g., Kades, supra note 16, at $436 \& \mathrm{n} .103$. Even a problem like maximizing the value of a fixed volume filled with objects drawn from a collection of objects of fixed value and volume is probably intractable; known as the "knapsack problem," it is NP-complete. Id. at 440-41.

31. For the role of delegation to owners in an information-cost theory of property, see, for example, Henry E. Smith, Exclusion and Property Rules in the Law of Nuisance, 90 VA. L. Rev. 965, 1021-45 (2004).

32. See, e.g., Carol M. Rose, The Several Futures of Property: Of Cyberspace and Folk Tales, Emission Trades and Ecosystems, 83 Minn. L. Rev. 129, 169-70 (1998); Henry E. Smith, Exclusion Versus Governance: Two Strategies for Delineating Property Rights, 31 J. LEgaL Stud. S453, S470-71 (2002).

33. J.E. Penner, The Idea of Property in Law 29-30, 71 (1997); Thomas W. Merrill \& Henry E. Smith, The Property/Contract Interface, 101 Colum. L. Rev. 773, 794-95 (2001); Merrill \& Smith, supra note 8, at 359; Smith, supra note 32, at S475; Smith, supra note 1, at 1151.

34. Smith, supra note 31; see also Richard A. Epstein, Nuisance Law: Corrective Justice and Its Utilitarian Constraints, 8 J. Legal StUd. 49 (1979). 
be explained as an effort to enforce the modularity of the property system. Likewise property owners-again very surprisingly from a legal realist or law and economics perspective-are not held responsible for anticipating the torts of others. ${ }^{35}$ The effect of this is to allow owners to concentrate more on the informational problems within rather than outside their module. ${ }^{36}$ Only when interactions become serious enough is it worthwhile for the law to prescribe the nature of the interaction (as in the law of nuisance or zoning) or for people to contract over them (easements and covenants).

This brings us to the question of what modularity has to do with contracts. In the examples above, contracting between parties involves a line of communication between them that is intensely used and all the more so the more their interaction is an ongoing one. A relational contract would involve the most information exchange, a simple sale of a discrete good the least. One might think therefore that modularity is relevant only to spot market transactions. And indeed it has been noticed before that markets and the property rights that make them possible do have the effect modularization. ${ }^{37}$ Adam Smith's invisible hand is remarkable in that results can be achieved with individuals not needing to know much about other people and their goals, or why prices are at their current level. ${ }^{38}$ Each actor's information is encapsulated but can nevertheless be brought to bear on the decisions of others through the interface conditions of the legal system and the market it supports.

But I will argue that the role of modularization in the law is much more far-reaching than this and partly because modularization is a matter of degree. Before turning to contract, it is worth pointing out that property law is modular on a more microscale than is often assumed in economics. Econo-

35. See LeRoy Fibre Co. v. Chi., Milwaukee \& St. Paul Ry., 232 U.S. 340 (1914). Wood's treatise describes a rule that is very different from the law of negligence:

It is the duty of every person or public body to prevent a nuisance, and the fact that the person injured could, but does not, prevent damages to his property therefrom is no defense either to an action at law or in equity. A party is not bound to expend a dollar, or to do any act to secure for himself the exercise or enjoyment of a legal right of which he is deprived by reason of the wrongful acts of another.

1 H.G. Wood, A Practical Treatise on the Law of Nuisances in Their Various Forms: INCLUDING REMEDIES THEREFOR AT LAW AND IN EQUITY § 435 (3d ed. 1893).

For surprise on the part of law and economics scholars, see, for example, Susan RoseAckerman, Dikes, Dams, and Vicious Hogs: Entitlement and Efficiency in Tort Law, 18 J. LegaL Stud. 25, 35-38 (1989); see also Mark F. Grady, Common Law Control of Strategic Behavior: Railroad Sparks and the Farmer, 17 J. Legal STUD. 15 (1988).

36. One aspect of this reduction in interconnectedness is the lack of owners needing to negotiate with others. See Harold Demsetz, Toward a Theory of Property Rights, 57 Am. Econ. Rev. (Papers \& Proc.) 347, 354-56 (1967); Robert C. Ellickson, Property in Land, 102 Yale L.J. 1315, 1327-28 (1993).

37. BALDWIN \& ClarK, supra note 5, at 100-14; Langlois, supra note 22, at 19-20.

38. See Adam Smith, An Inquiry into the Nature and Causes of the Wealth of Nations 423 (Edwin Cannan ed., Random House 1937) (1776) ("By pursuing his own interest [the individual] frequently promotes that of the society more effectually than when he really intends to promote it."); see also Vernon L. Smith, The Two Faces of Adam Smith, 65 S. Econ. J. 1 (1998). Hayek's argument that markets are decentralized information processors can also be interpreted as relying heavily on modularity. See F.A. Hayek, The Use of Knowledge in Society, 35 Am. Econ. Rev. 519 (1945). 
mists, including those of the neoinstitutional school, usually treat property and contract as indistinct; property rights are basically any ability to consume an asset in expected terms, either directly or indirectly through exchange. ${ }^{39}$ As with Coase, the tendency is to break up property into its smallest constituent parts and ask about the incentive effects each piece has on the relevant actors.

This misses a lot of what is going on. Property law does not atomize rights in this fashion. Instead, the default package starts off with a right to exclude from a space or thing (tangible or intangible). This is of course done because people have an interest in using things and want to protect their investments in those particular uses. But at this (foundational) point property law does not concern itself directly with these uses. Rather the right to exclude is based on a very simple on/off signal, that is, whether a person has entered Blackacre, has made off with an object, or has used an invention (patent). This permits actors to proceed largely in ignorance of each other and allows the state not to have to know much about the internal activities and choices of the owners.

Still, at this point we might say that the only role of modularity is in how the rights in the assets over which people contract tend to have some modular structure. The main source of modularity in property rights would be that people are not allowed through contract to alter the basic modular set up in the realm of property rights. ${ }^{40}$ Contracts may also be modular, largely because parties design them that way. To take a simple example, a warranty provision interacts with duty-creating provisions of a contract. We will return to many examples below. For now, it is just important to recognize that modularity is a matter of degree.

To save on costs among themselves, contractual partners may choose modular forms, and there is a growing awareness in the organizational literature that modularity is chosen in order to manage complexity. ${ }^{41}$ Even asset-partitioning can be viewed as an example of information-hiding and modularization: organizational law allows the information about the owner's dealings with his creditors to be irrelevant to the enterprise's contractual partners and sometimes makes information about the business's dealings irrelevant to the owner's creditors. ${ }^{42}$ Defining pools of assets and segregating them in this way provides for modularity and reduces the complexity and

39. Yoram Barzel, Economic Analysis of Property Rights 3 (2d ed. 1997) (defining property as "the individual's ability, in expected terms, to consume the good (or the services of the asset) directly or to consume it indirectly through exchange" (emphasis omitted)); Armen A. Alchian, Some Economics of Property Rights, 30 IL Politico 816 (1965), reprinted in ARmen A. Alchian, ECONOMIC ForCES AT Work 127, 130 (1977) ("By a system of property rights I mean a method of assigning to particular individuals the 'authority' to select, for specific goods, any use from a nonprohibited class of uses.”); see also Merrill \& Smith, supra note 8, at 358, 376-78.

40. Merrill \& Smith, supra note 3.

41. See, e.g., BALDWIN \& ClaRK, supra note 5; Langlois, supra note 22.

42. Henry Hansmann \& Reinier Kraakman, The Essential Role of Organizational Law, 110 Yale L.J. 387 (2000); see also Claire A. Hill, Securitization: A Low-Cost Sweetener for Lemons, 74 WASH. U. L.Q. 1061 (1996). 
transaction costs involved. It allows for specialization in monitoring assets: asset partitioning allows creditors to specialize in which persons and assets to monitor. ${ }^{43}$ Property itself allows owners to specialize in developing information about their assets.

Boilerplate exploits modularity, and this modularity in turn allows for a greater degree of complexity and specialization than would be possible otherwise. While specialization may arise without modularity, the informationhiding and standardized limited interfaces between modules enable those who are concerned with one module to develop and use information relevant to the module without having to worry about the impact of developments from elsewhere or ripple effects from their own activities-other than through the interface. As artifacts-including contracts and other legal relations-become more complex, more specialization is called forspecialization that modularity can support through its role in managing complexity. First, at some point the artifact cannot be made by one person, which requires division of labor. Even more complex artifacts cannot be comprehended in all their detail by a single mind, which calls for specialization of information. ${ }^{44}$ Modularity promotes both types of specialization, especially the latter. A boilerplate provision about governing law can be developed by those versed in choice of law without their having to know in detail about where the boilerplate provision will wind up-and without users of the boilerplate provision having to think through all of the possible scenarios involving choice of law. Even in more specialized contexts, treatises can offer standardized modular solutions by experts in construction contracts or software contracts, et cetera, without the authors having to consider how particular contracts might call for changes in the provision in question. ${ }^{45}$ As we will see, nondrafting parties, supported by drafting party incentives and certain interpretive doctrines, can specialize in their own business without having to approach contracts holistically. ${ }^{46}$ And, finally, judges can more easily afford to be legal generalists, which is to say they can specialize in legal analysis rather than business custom, when a great deal of contractual language they have to deal with is modular boilerplate.

There is little that is mandatory about all this. ${ }^{47}$ If a business organization is a nexus of contracts, then the contracts chosen will be highly modular because the benefits in reduced complexity costs are largely internalized to the contracting parties. If in some respects it is worthwhile to create intense

43. Hansmann \& Kraakman, supra note 42, at 399-405, 424-25.

44. BALDWIN \& CLARK, supra note 5, at 5.

45. Sometimes a lack of interaction with a relevant context increases the value of the provision. For example, in insurance contracts boilerplate is used in order to make the contract invariant to the actuarial context, thus allowing large pools of risk to be priced accurately. See Michelle E. Boardman, Contra Proferentem: The Allure of Ambiguous Boilerplate, 104 MicH. L. REV. 1105 (2006).

46. See infra text accompanying notes 136-141.

47. Other than an attempt by the law to channel people into a common vocabulary and rules of combination. 
contractual interaction among themselves, they can do so, but not in such a way that information flows increase to third parties, like other property owners, courts, and, to some extent, successors in interest. ${ }^{48}$

But modularity in contracts is more widespread than such a propertycentric view would suggest, and extends to a realm of contracts relatively untouched by contract theory-the drafting of contracts themselves. One of the cardinal rules of drafting contracts is to be sparing with cross-references. Each cross-reference is a source of interaction (communication if you will) between provisions of a contract, ${ }^{49}$ and so each cross-reference contributes to complexity. In more extreme cases, the interaction can take the form of potential cycles, which contribute greatly to complexity; some problems involving finding cycles are intractable. ${ }^{50}$

One source of nonmodularity - that is, interaction-is the mutual dependency of covenants. In modern contract law, a material breach by one party can excuse the performance of the other party. ${ }^{51}$ Thus, in addition to the explicit conditions in a contract, which expressly create interdependencies, the law treats substantial performance as a constructive condition of the other party's continued performance. This is a systematic interdependency between provisions, which the law provides and parties can contract around. One can imagine alternatives. Leases are particularly interesting, perched as they are at the interface between more modular property and less modular contract. ${ }^{52}$ Originally the covenants in leases were independent; if the landlord breached by not providing the premises, the tenant could sue but would not be excused from paying rent, and if the tenant failed to pay rent, the landlord could sue but would not be excused from providing possession to the tenant. ${ }^{53}$ In this, traditional leases were quite modular, but at some cost. The model of independent covenants was not well suited in particular to tenants whose expectation was (as it increasingly is) to acquire the services of a place to stay rather than a mini-property interest that gives them more discretion and more risk. ${ }^{54}$ Modern landlord-tenant law has gone a long way towards making covenants interdependent, but perhaps not quite as far in as in the law of contracts. This trend decreases the modularity of these provisions.

48. See Smith, supra note 1, at 1139-48, 1177-90.

49. This is also a rule for drafters of statutes. For a very interesting article on statutory drafting that recognizes the benefits of modularity through an analogy to object-oriented programming, see Thomas F. Blackwell, Finally Adding Method to Madness: Applying Principles of ObjectOriented Analysis and Design to Legislative Drafting, 3 N.Y.U. J. LegIS. \& PUB. PoL'Y 227 (2000).

50. See Kades, supra note 16, at 445-66.

51. See, e.g., E. Allan Farnsworth, Farnsworth on Contracts $§ 8.16$ (3d ed. 2004).

52. For an argument that landlord-tenant law is intermediate between in rem and in personam and also correspondingly intermediate in its degree of mandatoriness, see Merrill \& Smith, supra note 33 , at $820-33$.

53. Paradine v. Jane, (1647) 82 Eng. Rep. 897 (K.B.).

54. Merrill \& Smith, supra note 33, at 822-25. 
Another major source of modularity in contracts is the section on definitions. Definitions are now regarded with some suspicion because of doubts about the limits of language. These concerns are, I will argue, often overstated, and I return to the question of interpretation and formalism below. While recognizing that no definition can be totally context-independent, spelling out definitions increases modularity in at least two ways.

One is that the more explicit and formal the definition is, the less the contract interacts with the contracting context - other provisions of the contract, the parties' behavior, and the rest of the transacting context. Evidentiary rules associated with contracts increase contractual modularity. Again, I will return to a more precise approach to formalism below, but formalism is, I have argued, a matter of degree; instead of complete formalism or complete context-dependence, the law of necessity calls for differential formalism. ${ }^{55}$ The definitions allow closer approximation to a plain-meaning or four-corners approach. ${ }^{56}$ The sneering by some (but not all) legal realists and their successors at such rules is a little misplaced. ${ }^{57}$ The real question is whether the reduction in complexity costs from such definitions is worth the cost of devising them and the costs of potential distortions inherent in any attempt at formal definitions in contracts.

Definitions also function as modules themselves. As in a computer program, other parts of the contract can "call upon" them without the need to spell things out each time (which would entail a risk of error). Furthermore, if definitions are not segregated and done once and for all, contracts are open to an interpretive strategy where a use of the term in one part of the contract can more easily be used in interpreting the term in another part of the contract. This type of interpretation involves far more potential interaction-and hence more complexity - than in the case of a contract with a section on definitions. Concerns about nonexpert factfinders, and juries in particular, will be at their height in situations of high interaction. ${ }^{58}$ Also, in a modular structure, errors in interpreting one part of a contract-here some part related to a definition of a term-will be less likely to cause ripple errors elsewhere in the contract. But this insulation comes at a cost. It will be only those terms that occur often and are subject to the problems of holistic, highly complex interpretation that are good candidates for modular treatment. It turns out that boilerplate, while more internally complex than definitions, externally serves a very similar role in promoting modularity and managing complexity in contracts.

55. Smith, supra note 1, at 1167-90.

56. Id. at 1177-83. One aspect of differential formalism is the type of evidence admitted on contract interpretation questions. See Alan Schwartz \& Robert E. Scott, Contract Theory and the Limits of Contract Law, 113 YALE L.J. 541, 568-94 (2003).

57. See Smith supra note 1, at 1177-83; see also infra Section III.A.

58. Cf. Richard A. Posner, The Law and Economics of Contract Interpretation (John M. Olin Program in Law \& Econ., Working Paper No. 229, 2004). To this list may be added the objective theory of contract. See Joseph M. Perillo, The Origins of the Objective Theory of Contract Formation and Interpretation, 69 FORDHAM L. REV. 427 (2000). 


\section{B. Modular Boilerplate}

As contractual provisions go, boilerplate is characterized by a high degree of modularity. The word "boilerplate" has two senses, a wider and a narrower one. The broad "boilerplate" refers to any standardized term in a contract. But the word can also be used to refer to provisions that typically are found at the end of a contract and deal with recurring matters like assignment and delegation, successors and assigns, third-party beneficiaries, governing law and forum selection, waiver of jury trial, arbitration, remedies, indemnities, force majeure, transaction costs, confidentiality, announcements and notices, amendment and waiver, severability, merger, and captions. ${ }^{59}$ It is this type of boilerplate that I will be mainly concerned with in this Article.

Two of the most common types of boilerplate are governing law and severability provisions. Each of these typically occurs near the end of a contract. I argue that a quick survey of actual use of these provisions reveals a much higher degree of modularity than one would expect on the view of processing costs implicitly adopted in standard contract theory.

Consider first governing law or choice of law provisions. Most such provisions select the law of a single state or, even more commonly, a single state's law except for that state's conflict of laws rules. In a quick search of the Contracts and Organizations Research Institute ("CORI") contracts library, ${ }^{60}$ out of 220 governing law provisions, the largest group specified one jurisdiction (215 out of 220). Of these 215 clauses, there are three types. First, the seemingly simplest choice of law provisions (79 out of the 215 one-state clauses) select the laws of one state without qualification:

GOVERNING LAW This Agreement shall be construed in accordance with the laws of the State of Nevada. ${ }^{61}$

Second, about one and one-half times as commonly (120), one-state provisions select one jurisdiction except for that jurisdiction's choice of law, which could otherwise point to the laws of another jurisdiction. A typical example of the latter reads:

59. See, e.g., Tina L. Stark, Negotiating and Drafting Contract Boilerplate, at viixxii, 5 (2003).

60. The Digital Contracts Library of the Contracting and Organizations Research Institute ("CORI") [hereinafter CORI Contracts Library] is available with free registration at http://cori.missouri.edu. An initial search of the CORI Contracts Library was run on December 4 , 2005 for the phrase "governing law" contained in contracts filed between January 1, 2003 and December 31,2004 . This search yielded 22,280 contracts. A subset was created by sorting the results by CORI Contract ID number and taking the first contract of each set of 100 , along with the first contract of the last group. This yielded 223 contracts. (A search for "choice of law" gave more results but may skew the analysis in favor of the "other than choice of law" provisions, because such provisions also use the phrase "choice of law.")

61. Employment Agreement among Coi Solutions, Inc., Naipaul Communications, and Geeta Naipaul-Denton $\S 20$ (Sept. 30, 2001) (CORI Contract ID No. 1868), available at CORI Contract Library, supra note 60. 
Governing Law. This Agreement shall be governed by and construed in accordance with the laws of the State of Ohio, without regard to the choiceof-laws or conflicts-of-laws provisions thereof. ${ }^{62}$

Notice that this increases modularity and predictability. The law of Ohio here will apply without interaction with parts of the context relevant to Ohio's choice of law rules. Third and very similarly, some contracts (thirteen) choose the laws applicable to contracts made and to be performed wholly within that state, sometimes along with an agreement that the contract is such a contract:

Governing Law. The interpretation and construction of this Agreement, and all matters relating hereto, shall be governed by the laws of the State of New York applicable to agreements executed and to be performed solely within such State. ${ }^{63}$

Finally, a few (three) combined the language about applying the laws of one state without regard to conflict of laws with a clause about applying the law of that state that governs contracts made and to be performed entirely within such state.

Very rarely (five out of 220) did a contract select more than one jurisdiction or tailor the governing law provision by issue. For example, this could be a split by time:

GOVERNING LAW: THIS AGREEMENT AND THE RIGHTS AND OBLIGATIONS OF THE PARTIES HERETO SHALL BE GOVERNED, CONSTRUED AND ENFORCED IN ACCORDANCE WITH THE LAWS OF THE STATE OF UTAH UNTIL THE FINALIZATION OF THE FAIRNESS HEARING AND ENTRY OF ORDER REFERENCED IN PARAGRAPH 2, ABOVE, AND SAID FAIRNESS HEARING MUST BE BROUGHT AND CONCLUDED IN SALT LAKE COUNTY, STATE OF UTAH; THEREAFTER, THE OBLIGATIONS OF THE PARTIES HERETO SHALL BE GOVERNED, CONSTRUED AND ENFORCED IN ACCORDANCE WITH THE LAWS OF THE STATE NEW MEXICO AND THE PARTIES AGREE THAT OTHER THAN AS SET FORTH ABOVE, ANY LITIGATION RELATING DIRECTLY OR INDIRECTLY TO THIS AGREEMENT MUST BE BROUGHT BEFORE AND DETERMINED BY A COURT OF COMPETENT JURISDICTION WITHIN THE STATE OF NEW MEXICO ${ }^{64}$

Or it could be a split by issue:

62. Stock Purchase Agreement by and among Trimas Company LLC, The Shareholders and Option Holders of Highland Group Corporation, and FNL Management Corp. § 11.12 (Feb. 21, 2003) (CORI Contract ID No. 1448), available at CORI Contract Library, supra note 60 .

63. Preferred Stock Subscription Agreement Between Gregory Abbott and International Dispensing Corporation $\S 8.3$ (Jan. 24, 2003) (CORI Contract ID No. 9), available at CORI Contract Library, supra note 60.

64. Acquisition Agreement between United States Oil Company and Rocky Mountain Energy Corporation $\S 26$ (filed Jan. 14, 2003) (CORI Contract ID No. 4127), available at CORI Contract Library, supra note 60. 
Governing Law. This Exchange and Registration Rights Agreement shall be governed by and construed in accordance with the laws of the State of New York except that the authorization and execution of this Exchange and Registration Rights Agreement by the Guarantor shall be governed by the laws of the United Mexican States. ${ }^{65}$

Interestingly, even though they do not seem significantly more expensive to write, the sample contains only one provision that makes reference to the laws of more than two jurisdictions:

GOVERNING LAW; JURISDICTION. This Supplemental Indenture shall be governed by and construed in accordance with the laws of the State of California except (i) with respect to Article III hereof and the Guarantee, which shall be governed by and construed in accordance with the laws of the State of New York, without regard to conflicts of law provisions and (ii) with respect to authorization and execution of this Supplemental Indenture by or on behalf of the Guarantor which are required to be governed by the laws of the Netherlands....

Even here conflict of law principles and rules are cut off.

In two of these multiple-jurisdiction clauses, the split is more apparent than real, because the parties are simply (and redundantly) acknowledging that a different state's law will apply to the internal affairs of a corporation or a trust involved in the contract:

(f) Governing Law. The corporate law of the State of Delaware will govern all issues concerning the relative rights of the Company and its stockholders. All other issues concerning this Agreement shall be governed by and construed in accordance with the laws of the State of New York without giving effect to any choice of law or conflict of law provision or rule (whether of the State of New York or any other jurisdiction) that would cause the application of the law of any jurisdiction other than the State of New York. ${ }^{6}$

Another similarly selects California law for an indenture but makes an exception for the New York trust law to be applied to the trustee. ${ }^{68}$

The overwhelming selection of one state, especially barring choice of law, makes for extreme modularity. By selecting one state, these contracts are displacing off-the-rack law that might involve nonmodular and hard-to-foresee

65. Letter Agreement-Exchange And Registration Rights Agreement-Pemex Project Funding Master Trust between Petroleos Mexicanos and Credit Suisse First Boston LLC § 18(e) (June 4, 2003) (CORI Contract ID No. 64272) (emphasis on entire passage omitted), available at CORI Contract Library, supra note 60.

66. Supplemental Indenture among Transamerica Finance Corp, Aegon NV and BNY Midwest Trust Co $\S 6.8$ (filed Aug. 27, 2003) (CORI Contract ID No. 63374), available at CORI Contract Library, supra note 60.

67. Executive Agreement between Ziff Davis Holdings Inc., Ziff Davis Publishing Inc., and Gregory Barton § 18(f) (October 23, 2002) (CORI Contract ID No. 42453) (emphasis on entire passage omitted), available at CORI Contract Library, supra note 60.

68. Indenture between WFS Financial 2003-1 Owner Trust and [a New York banking corporation in its capacity as trustee] $\S 11.13$ (filed Mar. 25, 2003) (CORI Contract ID No. 48455), available at CORI Contract Library, supra note 60. 
choice of law questions, including the potential of cycling. By blocking a state's conflict of laws rules, the provision is even more modular: the choice of the law of a certain state will not vary with changes in the business or contract context. ${ }^{69}$ Here increased length promotes simplicity through modularity.

Again, it is not writing costs that prevent more tailored governing law provisions than the foregoing boilerplate. Tailored provisions like the "threeway" governing law provision or ones even more nuanced than that are not prohibitive to write. The real problem, I suggest, is their nonmodularity, leading to "reading costs" as I will interpret that term. The benefits from tailoring do not outweigh the greater complexity stemming from interactions.

Severability clauses serve modularity in multiple ways. Their purpose is to make the validity and enforceability of provisions less interdependent, which increases modularity. The validity of each provision can be considered more in isolation than in the absence of severability. As in many systems, modularity insulates the system as a whole from the failure of one part. A severability provision in a contract can be taken as an expression by the parties for modularity and against remodularization by courts.

Severability provisions also are very modular in that they apply across the board. A typical provision will apply to the entire contract:

SEVERABILITY OF THIS AGREEMENT. If any provision of this Agreement shall be judicially determined to be invalid, illegal or unenforceable, the validity, legality and enforceability of the remaining provisions shall not in any way be affected or impaired thereby. ${ }^{70}$

We overwhelmingly do not find provisions that make some proper subset of the contract's provisions severable. In a quick search of a sample of contracts from the CORI database, most (147 of 156) containing a severability clause had the across-the-board type like the one above. ${ }^{71}$ Again the problem is not writing costs, especially when one considers that thirty-six out of the 147 had one of several related extra provisions mostly to the effect that if a provision was severed the parties would bargain in good faith to replace it with a similar but valid one. ${ }^{72}$ Moreover, advice books promote the

69. For an interesting discussion of how adding this and several further phrases to a choice of law provision prevent complicated issues from arising, see STARK, supra note 59, §6.02[3], at 120.

70. Warrant Repricing Agreement Among Aradigm Corporation and Holders $§ 8.5$ (Feb. 10, 2003) (CORI Contract ID No. 1470), available at CORI Contract Library, supra note 60.

71. CORI, Contract Search, http://ronald.cori.missouri.edu/cori_search/client_search.php (last visited Jan. 11, 2006). The initial search, performed on December 2, 2005, was for "severability" in contracts filed between January 1, 2003 and December 31, 2004 (15,502 contracts), taking the first of every group of 100 along with the first contract of the last group, listed by CORI ID number, for a total of 156 contracts.

72. See, e.g., Joint Management Agreement among SGN LLC, Dex Holdings LLC, Qwest Dex, Inc, and Qwest Communications International Inc. 88.8 (Nov. 8, 2002) (CORI Contract ID No. 3527), available at CORI Contract Library, supra note 60 ("SEVERABILITY. If any provision of this Agreement is held to be unenforceable for any reason, it will be adjusted rather than voided, if possible, to achieve the intent of the Parties. All other provisions of this Agreement will be deemed valid and enforceable to the extent possible."); Separation Agreement between DOR Bio- 
idea of drafting an "essential terms" clause, which specifies particular terms whose invalidity or unenforceability will cause the contract as a whole to fail. And there were only a few examples splitting by the criterion of essentialness:

PARTIAL INVALIDITY AND SEVERABILITY. All rights and restrictions contained herein may be exercised and shall be applicable and binding only to the extent that they do not violate any applicable laws and are intended to be limited to the extent necessary to render this Agreement legal, valid and enforceable. If any term of this Agreement, or part thereof, not essential to the commercial purpose of this Agreement shall be held to be illegal, invalid or unenforceable by a court of competent jurisdiction, it is the intention of the parties that the remaining terms hereof, or part thereof shall constitute their agreement with respect to the subject matter hereof and all such remaining terms, or parts thereof, shall remain in full force and effect. To the extent legally permissible, any illegal, invalid or unenforceable provision of this Agreement shall be replaced by a valid provision which will implement the commercial purpose of the illegal, invalid or unenforceable provision. ${ }^{73}$

Again, these do not seem too expensive to write. ${ }^{74}$ Either of these approaches, based on inferring intent or essentialness, involve a higher degree of interdependency with the rest of the contract, because it will depend on the rest of the contract and the context of the deal what the overall intent of the parties is or whether a given provision is essential.

A couple of contracts have a severability provision that is general with only a narrow exception, thus keeping the interaction localized. One contract referred to a specific issue for special treatment (in the nature of an acceleration clause):

Severability. In case one or more provisions, or part thereof, contained in this Agreement or in any of the other Financing Documents shall be invalid, illegal or unenforceable in any respect under any Law, then without need for any further agreement, notice or action:

(a) The validity, legality and enforceability of the remaining provisions shall remain effective and binding on the parties thereto and shall not be affected or impaired thereby;

(b) The obligation to be fulfilled shall be reduced to the limit of such validity;

Pharma, Inc. and Colin Bier $§ 13$ (June 13, 2002) (CORI Contract ID No. 7036), available at CORI Contract Library, supra note 60 ("Severability. If any provision of this Agreement is, for any reason, invalid or unenforceable, the remaining provisions of this Agreement will nevertheless be valid and enforceable and will remain in full force and effect. Any provision of this Agreement that is held invalid or unenforceable by a court of competent jurisdiction will be deemed modified to the extent necessary to make it valid and enforceable and as so modified will remain in full force and effect.").

73. Agreement for Purchase and Sale of Assets Among Scientific-Atlanta, Inc., Arris International, Inc., and Texscan De Mexico, S.A. De C.V. § 12.6 (Nov. 13, 2002) (CORI Contract ID No. 14121), available at CORI Contract Library, supra note 60.

74. See, e.g., STARK, supra note 59, § 17.05[3], at 552-53. 
(c) If such provision or part thereof pertains to the repayment of the Obligations, then, at the sole and absolute discretion of the Lender, all of the Obligations shall become immediately due and payable; and

(d) If the affected provision or part thereof does not pertain to repayment of the Obligations, but operates or would prospectively operate to invalidate this Agreement in whole or in part, then such provision or part thereof only shall be void, and the remainder of this Agreement shall remain operative and in full force and effect. ${ }^{75}$

One other contract, an employment agreement, has a severability clause that governs within one section of the contract (on the protection of confidential information) and a general severability provision for the rest of the contract. $^{76}$ Tailored severability clauses in actual contracts are quite rare, despite the conventional advice and the apparent low cost of drafting.

Boilerplate contributes to modularity in contracts in specific ways. The functions of modularity can be captured by a variety of "modular operators,",77 and one can find boilerplate serving these more specific functions as well.

\section{Splitting or Decomposition}

Modularity involves splitting a system into relatively autonomous components. Simon refers to a decomposable or nearly decomposable system. Decomposability is a matter of degree. The more each module is isolated, the more decomposable the system. The trick is to find the natural fault lines in a problem. ${ }^{78}$ In property these fault lines are around groups of complementary attributes and sometimes track prelegal natural boundaries. ${ }^{79}$ To some extent modularity can be imposed on a system by preventing some communication that would have some positive benefit. To take a property example from earlier, surely there would be some benefit in holding people responsible for knowing the particular features of an owner and holding owners responsible for anticipating the torts of others, but this benefit is probably quite small in comparison to the large addition to the complexity of the problems facing owners and dutyholders. ${ }^{80}$ Likewise with the numerus clausus, which limits the forms of property to a fixed and finite list: one might be able to find some property arrangement that is made prohibitively

75. Financing Agreement between Town And Country Trust, TC Operating Limited Partnership, and TC Property Company II; and First National Bank Of Maryland $\S 8.4$ (Sept. 25, 1998) (CORI Contract ID No. 8023), available at CORI Contract Library, supra note 60.

76. Employment Agreement Between Power Efficiency Corporation and Raymond J. Skiptunis $\S 14$ (Nov. 7, 2002) (CORI Contract ID No. 2601), available at CORI Contract Library, supra note $60 ; i d . \S 10$. This nesting promotes modularity over clause that directly separated an issue like the protection of confidential information out for special treatment.

77. BALDWIN \& ClaRK, supra note 5, at 12-13, 123-46.

78. See, e.g., Langlois, supra note 22, at 24-26; Simon, supra note 13, at 195-98. This is sometimes called "factoring."

79. See supra note 32.

80. See supra notes 33-36. 
costly by the numerus clausus principle, but some such frustration costs will be worthwhile to incur in the interests of greater modularization. ${ }^{81}$ In the case of property interests, these frustration costs are kept lower than they otherwise would be because the very simple rules for combining basic interests feed each other-and themselves-allowing them, like Lego blocks, to accomplish a surprisingly wide variety of objectives at low cost. ${ }^{82}$ In boilerplate, certain parts of the contract are hived off into sections that deal with questions like choice of law or arbitration.

\section{Substitution}

Because modules only interact in specified ways consistent with an overall general function they are supposed to perform (again, think of a print-control module in a computer program), one module can be substituted for another as long as they perform the specified function. This principle is put to widespread and powerful use in object-oriented programming, where functions are made into objects that have hidden internal structure and that can be substituted for one another. One of the great attractions of boilerplate is that one provision can be substituted for another related provision.

\section{Augmentation}

If an issue is suitable for modular treatment, a new module can be added to the system without much disruption to the rest. Thus on some issues like choice of law, boilerplate can be added without having to worry about extensive revisions elsewhere in the contract.

Notice that the addition of a module of boilerplate can be regarded as either substitution or augmentation depending on whether the frame of reference is the contract itself or the contract as embedded in the background of the common law or statute. Thus, to take the example of choice of law again, adding a choice of law provision to a contract that lacks one is augmentation if we are considering the contract as the system. But if the contract plus off-the-rack law is taken as the system, the addition of the choice of law boilerplate is the substitution of the boilerplate for the off-therack law (which might prescribe the state in which the business dealings occurred as a default.) Precisely because the law of contractual defaults is supposed to apply transsubstantively to a wide variety of contracts, it is likely to be at least as modular as the boilerplate that might displace it. ${ }^{83}$ Furthermore, because contractual defaults might be expected to be very modular, when commentators have argued over whether defaults should be

81. Merrill \& Smith, supra note 3, at 35-38.

82. Id. at $36-37$.

83. Before one could decide on the optimal degree of modularity here one would have to recognize that any tendency of courts to favor off-the-rack defaults as presumptively fair and to make contracting around them difficult might result in too much modularity in contracts. See Charles J. Goetz \& Robert E. Scott, The Limits of Expanded Choice: An Analysis of the Interactions Between Express and Implied Contract Terms, 73 CAL. L. REv. 261 (1985). 
more tailored to particular business contexts, the more salient advantages of such tailoring must be offset against the loss of the advantages of modularity that are the focus of this Article. ${ }^{84}$

\section{Exclusion}

Likewise, a module can be subtracted without major perturbations. For example the choice of law boilerplate module can be subtracted and the general off-the-rack choice of law principles will apply. Consider the previous examples of augmentation, which could work in reverse (for example, striking a choice of law boilerplate provision). This is modularity acting through the operator of exclusion.

\section{Inversion}

The process of inversion takes a previously hidden function, often repeated in many modules, and factors it out, moving it higher up in the hierarchy of the design so that it is visible and can be called upon by the various other modules. ${ }^{85}$ In software a typical example would be moving the print function higher up and making it into a module that other modules can use in defined ways. ${ }^{86}$ In the realm of contracts, the definition sections can emerge from such a process. Closely related definitions (implicit or explicit) of a given term buried in substantive provisions can be factored out and placed with the definitions in their own module.

\section{Porting}

Modules can be borrowed from one system and plugged into another. As long as the connections between the module and the exterior world (the rest of the system, especially the contract and the business context) are few and standardized, this process of porting will not cause disruptions. Porting is one of the chief virtues of boilerplate and what allows it to become the subject of a valuable body of judicial interpretations. Form books and treatises only make sense with a high degree of portability. Indeed the complaint of lawyers is that they imply a greater than optimal degree of portability. ${ }^{87}$

At this point one might ask whether things could be otherwise. Is the current degree of modularity the only way contracts and other aspects of

84. One of the central issues in contract theory has been over whether courts are in a position to create detailed default rules that would be sensitive to features of the parties such as their information, the risks they can bear, and who is the cheapest cost avoider in various business contexts. Compare Alan Schwartz, The Default Rule Paradigm and the Limits of Contract Law, 3 S. CAL. INTERDISC. L.J. 389 (1993), with Ian Ayres \& Robert Gertner, Strategic Contractual Inefficiency and the Optimal Choice of Legal Rules, 101 YaLE L.J. 729 (1992).

85. BALDWIN \& ClaRK, supra note 5, at 138-40.

86. Id. at 138 .

87. For advice on how to pay attention to the ramifications of boilerplate, see STARK, supra note 59 , at 5 . 
legal relations could be organized? The answer is no. First of all, as we will see, some of the traditional aspects of the law coming under the headings of formalism and conceptualism had the effect of making law more modular. Moving away from them has decreased modularity, at the cost of added complexity. When moving in this direction, the lessons from wellunderstood areas like computer design and programming can point to overlooked costs of the highly context-dependent style of legal reasoning so favored by the realists and their successors. ${ }^{88}$

Another way to understand modularity is to examine superficially similar artifacts produced by very different processes and institutions. In this Article I am concerned mostly with contracts - and their contrast with property. Contract drafting has something in common with legislation, and many of the features of modularity apply to legislative drafting as well. Tips on legislative drafting include the use of modular techniques. ${ }^{89}$ In both contracts and statutes, cross-references are a type of interaction that defeat modularity, increase complexity, and create traps. ${ }^{90}$ For example, the drafters of the new Texas Business Organizations Code, ${ }^{91}$ effective on January 1, 2006, made a conscious effort to introduce a "hub and spoke" model that would set out provisions common to all business organizations separately (for example, general definitions and provisions about mergers) and avoid duplication (Title 1), with specific titles for corporations, partnerships, et cetera. ${ }^{92}$ One of the members of the drafting committee set out how lessons from object-oriented analysis and design could inform exercises like this in legislative drafting. Although he does not use the term modularity, it is implicit in many of the lessons he draws. ${ }^{93}$

This advice presupposes one-time drafting with a comprehensive view that allows a conscious modularization in the first place. But not all legislation is like this. Consider the Internal Revenue Code, which is often cited as

\section{Take one example:}

As Justice Brennan candidly admitted in Penn Central . . . whether or not a government action is a taking "depends largely "upon the particular circumstances [in that] case." The Court must engage in "essentially ad hoc, factual inquiries."

But is anything wrong with "essentially ad hoc, factual inquiries?" That is simply one way of expressing a pragmatic approach to decision making. Pragmatism is essentially particularist, essentially context-bound and holistic; each decision is an all-things-considered intuitive weighing.

Margaret Jane Radin, The Liberal Conception of Property: Cross Currents in the Jurisprudence of Takings, 88 Colum. L. Rev. 1667, 1680 (1988) (quoting Penn Cent. Transp. Co. v. New York City, 438 U.S. 104, 124 (1978) (alteration in original) (footnotes omitted)).

89. Thomas F. Blackwell, Finally Adding Method to Madness: Applying Principles of Object-Oriented Analysis and Design to Legislative Drafting, 3 N.Y.U. J. LeGis. \& PuB. PoL'y 227 (1999-2000).

90. See, e.g., Scott A. Baxter, Reference Statutes: Traps for the Unwary, 30 McGeorge L. Rev. 562 (1999).

91. Tex. Bus. Orgs. Code AnN. (Vernon 2006).

92. Blackwell, supra note 89 , at 249-57.

93. Id. at 268-88. 
the ultimate example of a complex law. One of the features that makes it complex is the large number of cross-references from one section to another, the cognitive costs of which were colorfully described by Judge Learned Hand:

In my own case the words of such an act as the Income Tax, for example, merely dance before my eyes in a meaningless procession: cross-reference to cross-reference, exception upon exception-couched in abstract terms that offer no handle to seize hold of-leave in my mind only a confused sense of some vitally important, but successfully concealed, purport, which it is my duty to extract, but which is within my power, if at all, only after the most inordinate expenditure of time. I know that these monsters are the result of fabulous industry and ingenuity, plugging up this hole and casting out that net, against all possible evasion; yet at times I cannot help recalling a saying of William James about certain passages of Hegel: that they were no doubt written with a passion of rationality; but that one cannot help wondering whether to the reader they have any significance save that the words are strung together with syntactical correctness. ${ }^{94}$

This is nonmodularity. Not only are there many cross-references, but the Internal Revenue Code does not make use of concepts that apply across different settings. Notoriously, the Code does not have a unified conception of ownership, to which other provisions could "call" in modular fashion. ${ }^{95}$ Instead ownership is defined explicitly or implicitly for a variety of purposes in particular parts of the Code.

Why is the tax code not as modular as one could imagine? Two reasons go a long way towards explaining the relative lack of modularity here. First, unlike in some areas of the law, each part of the Code is subject to potential manipulation by parties and telling them the exact contours of what is allowed can be an invitation to evade in hard-to-foresee ways. Ownership and control sometimes cut in favor of the taxpayer and sometimes against, and particularly in antiabuse provisions, lack of detail can be manipulated by taxpayers. ${ }^{96}$ Thus, formalism (including modularity) is less practicable in tax law than in other areas. Second and relatedly, the tax code is the subject of intense lobbying and continual fixes in response to taxpayer manipulation. This takes the form of changes that would be prohibited by a strong form of modularity. New forms of evasion or new provisions, such as those govern-

94. Learned Hand, Thomas Walter Swan, 57 YALE L.J. 167, 169 (1947). Seeing increasing complexity as a trend, Hand went on:

Much of the law is now as difficult to fathom, and more and more of it is likely to be so; for there is little doubt that we are entering a period of increasingly detailed regulation, and it will be the duty of judges to thread the path-for path there is - through these fantastic labyrinths. Id.

95. Nöel B. Cunningham \& Deborah H. Schenk, Taxation Without Realization: A "Revolutionary" Approach to Ownership, 47 TAx L. Rev. 725, 727 (1992) (noting that the Code has no unified conception of ownership and arguing for extension of the approach behind section 1286 rules for bonds with attached coupons to defining ownership under the Code generally).

96. Wayne M. Gazur, The Forgotten Link: "Control” in Section 482, 15 Nw. J. InT'L L. \& Bus. 1, 11-14 (1994); see also David A. Weisbach, Formalism in the Tax Law, 66 U. CHI. L. Rev. 860 (1999) (discussing sources of complexity for anti-abuse rules as opposed to standards). 
ing new financial instruments, call for very different conceptions of ownership. Some simple one-size-fits-all version of ownership would be a sitting duck for taxpayers and lobbyists.

The example of the tax code underlines the importance of the process by which a modular system will or will not evolve. There are powerful forces pushing in the direction of modularity. The human mind—and this includes those of judges and the creators of artifacts like contracts as well as their contracting partners, who need to be persuaded to reach an agreementfinds modular structures much easier to deal with cognitively. Further, in any environment in which these forms are subject to selection pressure, modularity may have major advantages. In a wide variety of settings, modular structures possess an advantage in terms of evolvability. A module can be added, subtracted, altered, et cetera, in response to stress from outside the system, without causing the rest of the system to fail. That modularity is a way of allowing complex systems to be more adaptive is now central to biological models of evolution. ${ }^{97}$ Even modularization of the system itself can be favored in the evolution of evolvability.

When modularization is planned rather than evolved, it is difficult to establish which version of a decomposition (or even degree of decomposition) of a problem is the right one. Moreover, those creating systems do not always have the right incentives to adopt the optimal degree of modularity. People writing a contract or those creating a property interest may not care enough about the wider system of legal relations and the audiences for rights who have no say in the creation of idiosyncrasies by the parties themselves. I turn to these incentive problems and the externalities they give rise to in the next Part.

Before turning to a simple model of the role of modularity in defining legal relations, it is worthwhile to consider how the benefits and costs of modularity differ depending on the nature of the parties. Between sophisticated parties, one might think that common knowledge would make modularity unnecessary. The more parties are familiar with and can trust each other, the less they have to worry about traps. ${ }^{98}$ Nonetheless, complex interaction is difficult to deal with even for the sophisticated-a point to which I return in the next Part. But for now consider relatively unsophisticated parties. While it is true that sometimes marginal consumers can discipline sellers into offering efficient terms to everyone, the conditions for this to happen may not hold. ${ }^{99}$ If not, doctrines like procedural unconscionability (and

97. See sources cited supra note 15 .

98. The possibility of strategic behavior may make any system vulnerable. A modular system might be more easily manipulated because it is easy for the opportunist to understand or it can be difficult to game because the system has been designed to resist such behavior (and modularity can make such defensive design easier for the architect to achieve).

99. See, e.g., Richard Hynes \& Eric A. Posner, The Law and Economics of Consumer Finance, 4 Aм. L. \& Econ. Rev. 168, 170-77 (2002); Alan Schwartz \& Louis L. Wilde, Imperfect Information in Markets for Contract Terms: The Examples of Warranties and Security Interests, 69 VA. L. REv. 1387, 1401-29 (1983) (showing that, just as with price diversity where consumers prefer one price, the variety of contract terms can affect consumer search costs); Alan Schwartz \& 
reasonable expectations in insurance law) can give consumers some assurance that they will not be out in the cold if they treat various contractual provisions as modular. ${ }^{100}$ The internal workings of a provision, particularly if it looks standard but actually is not, should be treated as if it is standard unless prominent notice is given. ${ }^{101}$ Prominent notice is a more expensive way to communicate-what I will call intensive in the following-and its benefits are subject to increasing marginal cost. (Putting the whole contract in boldface doesn't do much.)

Likewise the doctrine of contra proferentem is usually justified on the basis that the drafter, often but not always the more sophisticated party, might otherwise have an incentive to leave strategic ambiguities. ${ }^{102}$ Under the contra proferentem rule, ambiguities are resolved in favor of the nondrafting party. The drafter is presumed to be the cheapest cost avoider. For present purposes it is worth pointing out that the contra proferentem rule means that the costs of complexity are brought home to the one putting the complexity there. Ambiguity is often the result of less-than-complete modularization; to resolve the ambiguity one must resort to context-either of the rest of the contract or of the deal itself. The contra proferentem rule truncates this type of interaction between a provision and its context and supplies the reading more favorable to the nondrafting party. This requires a minimal use of context by the judge and causes the drafting party to tend to avoid modularity-defeating, ambiguous provisions. The contra proferentem rule, however, should not be absolute. We want the drafting party to avoid ambiguity but not to try to eliminate every ambiguity — an unattainable, or at

Louis L. Wilde, Intervening in Markets on the Basis of Imperfect Information: A Legal and Economic Analysis, 127 U. PA. L. Rev. 630, 646-48 (1979); Alan Schwartz, How Much Irrationality Does the Market Permit? (Am. Law \& Econ. Ass'n Annual Meetings, Paper No. 29, 2005), available at http://law.bepress.com/alea/15th/art29).

100. Much of the cases and commentary view with suspicion a contracting process characterized by a "lack of a meaningful choice. ... consider[ing $\ldots$. . all the circumstances surrounding the transaction, including [t]he manner in which the contract was entered, whether each party had a reasonable opportunity to understand the terms of the contract, and whether the important terms [were] hidden in a maze of fine print." Schroeder v. Fageol Motors, Inc., 544 P.2d 20, 23 (Wash. 1975) (quoting Williams v. Walker-Thomas Furniture, 350 F.2d 445, 449 (D.C. Cir. 1965) (internal quotations omitted) (second and third alterations in original)); see Robert A. Hillman, The RichNess of Contract LaW: AN ANalysis and Critique of Contemporary Theories of Contract Law 138 (1997); Robert A. Hillman \& Jeffrey J. Rachlinski, Standard-Form Contracting in the Electronic Age, 77 N.Y.U. L. REv. 429 (2002). The information-cost theory suggests sharpening the issue to whether market conditions permit a seller to push nonmodularity well beyond the optimal point. An obvious case would be one in which a consumer contract was much less modular than a similar contract between sophisticated parties. Putting this idea into practice would not be easy but might weed out obvious cases of abuse. On the doctrine of reasonable expectations, see, for example, Kenneth S. Abraham, Distributing Risk: Insurance, Legal Theory, and Public Policy (1986), and Hillman \& Rachlinski, supra, at 459-60. Again, if the doctrine allows consumers not to read but to rely on the presence of only reasonable boilerplate, the reasonableness of the boilerplate should turn in part on the degree of modularization.

101. This familiar notice-giving strategy is particularly favored in contexts that straddle the contract-property divide in that the dutyholders are either numerous or indefinite. See Merrill \& Smith, supra note 33, at 803-09.

102. See, e.g., Kenneth S. Abraham, A Theory of Insurance Policy Interpretation, $95 \mathrm{MicH}$. L. Rev. 531 (1996); Posner, supra note 58, at 37. 
least not cost-effective, ideal. ${ }^{103}$ Nor, without more, is it obvious that the drafting party should be an unlimited insurer for all remaining ambiguity no matter how unforeseeable and unsusceptible to manipulation. As with the plain-meaning rule and prohibitions on extrinsic evidence, the point is that normatively the law should favor an approach that pushes drafting parties in the direction of minimizing-not eliminating-information costs to nondrafting parties, particularly unsophisticated ones.

\section{A Model of Modularity in Contract Boilerplate}

In this Part, I present a model of modularity in contractual boilerplate which captures how boilerplate is intermediate between contract and property. Once we apply the tools of information theory, we can show that context-dependence and its converse, formality, are matters of degree. If so, this calls into question the assumption in the traditional debate between realism and formalism that context-independence would have to be potentially total for formalism to make sense. Modularity, like other devices, pushes legal relations away from context-dependence and towards formality, but the real questions are what degree of modularity is optimal in various contexts and who has an incentive to bring the degree of modularity in a contract or other written instrument towards this optimal point.

\section{A. Formalism and Context-Dependence}

Before turning to a theory of optimal modularity, consider contextdependence and formality. The legal realists took the formalists of the latenineteenth and early-twentieth centuries to be arguing that language could be perfectly independent of context and that law could partly for that reason be an autonomous discipline, "legal science."104 Many realists believed that once they could show that interpreters relied on context even a little, that formalism was dead. ${ }^{105}$ And the formalists, not being big on theory, had little to counter with.

But formalism is a matter of degree, and this is fatal to the classic hyperrealist argument. For our purposes, a very useful definition of formalism is that offered by Francis Heylighen: formalism is the degree of invariance to context. $^{106}$ Thus, mathematical notation is very formal because each statement is expressed in a system with a precise syntax and semantics that allows interpretation to be largely, although not completely, context-dependent. Wellknown results point to the fact that ultimately some element of interpretation

103. See, e.g., Posner, supra note 58; Smith, supra note 1.

104. See, e.g., Paul N. Cox, An Interpretation and (Partial) Defense of Legal Formalism, 36 IND. L. REv. 57, 59-68 (2003) (discussing formalism as autonomous conceptualism as among varieties of formalism opposed by realists and their successors); Brian Leiter, Positivism, Formalism, Realism, 99 Colum. L. Rev. 1138, 1144-49 (1999) (book review); Smith, supra note 1, at 1177-83.

105. Smith, supra note 1, at 1180-81.

106. See Francis Heylighen, Advantages and Limitations of Formal Expression, 4 Found. SCI. 25, 49-53 (1999). 
will have to come from outside the system, but in mathematics this element is at its minimum (which is not zero). ${ }^{107}$ In their everyday work, mathematicians tend to use a somewhat less formal system that requires more contextual knowledge. Natural language comes in varieties that are more or less formal. For example, words like pronouns and demonstratives depend on context and contribute to a lesser degree of formality. This has led some linguists to propose an index of formalism in natural language and to use it in statistical analysis of natural language corpora. ${ }^{108}$

The repetition of noun phrases in contracts (for example, the party of the first part commits that the party of the first part will ...) is an examplesome would say an unfortunate example — of formalism. ${ }^{109}$ But notice that use of pronouns instead of full noun phrases increases the reliance on context and causes interactions of the type that are inconsistent with stricter forms of modularity. Tracing out all the possible interpretations of a passage with many pronouns can be very complex: there are many phrases requiring the assignment of an interpretation and the interpretations can interact in ways that are sometimes hard to foresee. ${ }^{110}$

Context-dependence and formalism have costs and benefits that are mirror images of each other. It is simply not the case that we always want maximum or minimum context-dependence (minimum or maximum formalism). Context-dependence allows messages to be short given the amount of information conveyed. Where those communicating share a lot of background knowledge, lack of formalism does not lead to misunderstanding because the parties can converge on an interpretation using their background knowledge. This sort of thing happens in everyday conversation in ways that are sophisticated but easy to ignore.

In everyday conversation a great deal of information can be packed into few words because both parties can rely on what Grice called the Cooperative Principle: " $[\mathrm{m}]$ ake your conversational contribution such as is required, at the stage at which it occurs, by the accepted purpose or direction of the

107. Id. at 34-38 (discussing nature of definitions, primitive terms, and "intrinsic limitations principles" such as Gödel's incompleteness theorem).

108. See, e.g., Jean-Marc Dewaele, How to Measure Formality of Speech? A Model of Synchronic Variation, in Approaches to Second Language Acquisition 119 (Kari Sajavaara \& Courtney Fairweather eds., 1996); see also Jean-Marc Dewaele, Style-Shifting in Oral Interlanguage: Quantification and Definition, in The Current State of Interlanguage 233 (Lynn Eubank, Larry Selinker \& Michael Sharwood Smith eds., 1995); Heylighen, supra note 106, at 4953.

109. See Peter M. Tiersma, Legal Language 71-73 (1999). The use of noun phrases instead of pronouns is a familiar aspect of context-dependence (called indexicality) and features in Dewaele's constructed variable of formalism. See sources cited supra note 108.

110. Pronoun reference is one of the most studied topics among generative grammarians. See, e.g., Gennaro Chierchia \& Sally McConnell-Ginet, Meaning and Grammar: An Introduction to Semantics 330-33 (2d ed. 2000); Richard Montague, Formal Philosophy: Selected Papers of Richard Montague (Richmond H. Thomason ed., 1974); Yehoshua BarHillel, Indexical Expressions, 63 Mind 359 (1954). 
talk exchange in which you are engaged." ${ }^{, 111}$ Because of this general principle and the background knowledge shared by the parties to a conversation, much can be communicated via conversational implicature. ${ }^{112}$ For example, people usually say something like "It's cold" in order to get someone standing near an open window to close it, rather than something like "I hereby request that you, being closer to the window than I, please close the window." The latter version would be more effective when dealing with someone who has never seen a window before. The second version is more formal because it can work in a wider variety of contexts, but it comes at the greater cost of more length and greater planning (not to mention greater syntactic complexity). The ability to lower the cost of the message itself by using conversational implicature and context (including audiences' background knowledge), versus the sacrifice of portability across those contexts, is an example of what I have termed the informational trade-off: everyday conversation is informationally dense (what I am calling "intensive") in that it compacts a lot of information per unit of communicative effort. ${ }^{113}$ When we want the message to reach a wider audience and more types of contexts, we have to engage in more (not complete) formalism by using messages that are costlier to create and to process.

Notice that conversational implicature's reliance on context not only makes conversational interpretation-usually called pragmatics by linguists-relatively informal, it also makes pragmatics nonmodular. ${ }^{114}$ Modularity, like formalism in general, is inconsistent with heavy reliance on context. Although it goes well beyond the subject of this Article, it is worthwhile to note that many aspects of natural-language competence, including syntax and even semantics, have been profitably studied by assuming that each of these subareas and components of them are implemented in the mind/brain by modules. Pragmatics is not one of them. Grice's Cooperative Principle looms large in pragmatics and should sound familiar to economists: it is the rational-actor paradigm in the realm of conversation. ${ }^{115}$ Instead, the assumption in pragmatics is that general cognitive abilities come into play, and pragmatics either does not emphasize cognitive limits (as in Grice) or focuses on limits on general, not modular cognition.

111. H.P. Grice, Logic and Conversation, in 3 Syntax and Semantics 41, 45 (Peter Cole \& Jerry L. Morgan eds., 1975), reprinted in PaUl Grice, Studies In the Ways of Words 22, 26 (1989).

112. Grice, supra note 111, at 30; see also Stephen C. Levinson, Presumptive Meanings: The Theory of Generalized Conversational Implicature (2000) (recent development of Gricean theory).

113. Smith, supra note 1, at 1110-11,1126-33.

114. See generally Stephen C. Levinson, Pragmatics (1983); Dan Sperber \& Deirdre Wilson, Relevance: Communication and Cognition (1986).

115. See Jay David Atlas \& Stephen C. Levinson, It-Clefts, Informativeness, and Logical Form: Radical Pragmatics (Revised Standard Version), in Radical Pragmatics 1 (Peter Cole ed., 1981); Richard Craswell, Do Trade Customs Exist?, in The Jurisprudential Foundations of Corporate and Commercial LaW 132 (Jody S. Kraus \& Steven D. Walt eds., 2000); H. Paul Grice, Further Notes on Logic and Conversation, in 9 SyntaX and Semantics 113 (Peter Cole ed., 1978), reprinted in GRICE, supra note 111, at 41. 
By contrast, modular aspects of mind, like language competence (and vision, et cetera), are easier to study precisely because of their modularity and the constraints that imposes. ${ }^{116}$ If central processes (as opposed to modular ones like perception and language with specific neural structures) approach universal connectivity, interesting patterns emerge because of the outer environment and not from the constraints imposed by internal mental modularity. I would like to suggest something similar for law and economics. The more modular an artifact is, the easier it is to study, and the more a decisionmaking process is modular and leads to modular artifacts, the more amenable it is to the tools of analysis that are available both to economists and cognitive scientists. I suggest that the reason that law and economics has been especially successful in the study of the common law, as opposed to legislation and constitutions, ${ }^{117}$ is that common law judges proceeding case-by-case have fashioned modular principles that are easier to analyze than the typical outputs of legislative or administrative bodies.

What happens when stakes are high? Parties can invest in developing background knowledge and trust or they can invest in more formalism in the written agreements that govern their relationship. But where parties do not share much background and cannot develop it cost-effectively, formalism may increase the cost of the message but reduce error costs. Where people do not share much background knowledge or have interests antagonistic to each other, it becomes worthwhile to invest in greater formality in order to avoid the high error costs. High stakes thus do not unambiguously point in either direction if we take a very ex ante perspective. However, if we take the level of background knowledge as given, then an increase in the stakes as between these parties suggests an increase in formalism. And high-stakes deals are associated with more formal agreements in this relativized sense.

The choice of a degree of formalism is subject to what I have called elsewhere the informational trade-off. Intensive communication involves a lot of information per unit of communicative effort. But increasing the intensiveness of communication will require either incurring more communication costs or reducing the extensiveness of the audience and the ability to draw on context in general. At a given cost there is a trade-off between intensiveness and extensiveness of communication. Property is more formal (less context-dependent), and, being in rem, is meant to reach a larger audience. In general, property interests can be mixed and matched and used in a wide variety of contexts. They are very portable in a way that they would not be if they were tailored to individual situations. ${ }^{118} \mathrm{Cer}-$ tain features of a fee simple of a lease hold true regardless of the nature of the asset and the holder of the interest. This makes property rights very

\footnotetext{
116. See Fodor, supra note 14, at 101-19.

117. A prominent example of nonmodular legislation is the tax code. See supra notes 94-96 and accompanying text.

118. The types of property rights are limited to a fixed and finite number under the numerus clausus, and the ones allowed first should be the most widely useful. Merrill \& Smith, supra note 3, at 39 .
} 
easy to decipher. It also makes furnishing notice to purchasers and potential violators much cheaper.

Modularity is one method of reducing dependence on context. A modular provision in a contract or a modular property right can be added, subtracted, transported, et cetera, into new contexts. And the removal or change of a module does not cause problems, because the module interacts relatively little with the context. As long as the interface conditions are obeyed, one need not worry further about the context. For example, if a choice of law boilerplate provision is modified or replaced, one need not hunt through a contract to find all the hidden connections that might lead to difficult-to-foresee problems. Some attention needs to be paid to such potential problems because formalism (invariance to context) is not and cannot be complete, but a less modular provision would require a great deal more revising of a holistic sort and would greatly increase reading costs to the other party.

\section{B. An Information-Theoretic Model of Boilerplate}

We can capture this trade-off and begin to explain the nature of boilerplate and the costs of reading it by extending a simple isocost model of information costs. Information is measured by bits in information theory; each bit can eliminate up to half of a set of possibilities. ${ }^{119}$ The more improbable a message is, the more bits are required to capture it. Elsewhere I have defined intensiveness of communication as the information rateinformation per unit of delineation cost. ${ }^{120}$ Likewise, we will be concerned with how far a communication can travel. We can construct an index of compatibility to context (extensiveness) by taking the number of contexts in which the message must function, each context weighted by the probability of its occurrence. ${ }^{121}$

Holding the costs of producing and receiving a message about legal relations constant, one must trade off the intensiveness of the communication with the extensiveness of the set of contexts into which the communication can fit. On the intensive side, a message can have a high information rate and heavy reliance on (specialized) contexts. Think of a highly idiosyncratic contract term. Or, on the extensive side, one can make the message easier to fit into a wider range of contexts but will have to lower the information rate: spelling things out will cause the rate of information per unit of communication cost to

119. See C.E. Shannon, The Mathematical Theory of Communication (Part 1), 27 Bell Sys Tech. J. 379 (1948), reprinted in Claude E. Shannon \& Warren Weaver, The Mathematical Theory of Communication 3 (1949); C.E. Shannon, The Mathematical Theory of Communication (Part 2), 27 Bell Sys. Tech. J. 623 (1948), reprinted in Shannon \& Weaver, supra, at 3; see also Keith Devlin, Logic and Information 3-26 (1991) (adapting information theory to individual messages); Fred I. Dretske, Knowledge and the Flow of Information 142 (1981); R.V.L. Hartley, Transmission of Information, 7 BeLL SYs. TECH. J. 535 (1928) (developing notion of "amount of information").

120. Smith, supra note 1, at 1109-11, 1126-33.

121. Id. at 1111-13, 1133-39. Here I take context to be defined by economically important features of the environment, not just audience characteristics. 
go down. All else equal, increased extensiveness requires decreased intensiveness. This can be modeled by an isocost reflecting a budget to be allocated between average information rate (intensiveness) and the compatibility with context (extensiveness). Points along the line connecting the two axes in Figure 5 all represent different combinations of information rate and wideness of context that are equally costly. Additional isocost lines to the northeast in the Figure, not drawn here, would involve a greater level of cost. In Figure 5, this is illustrated with information rate $(r)$ on the $y$-axis and (weighted) number of reachable contexts $(n)$ on the $x$-axis. ${ }^{122}$

\section{FIGURE 5}

\section{The Communicative Trade-OfF}

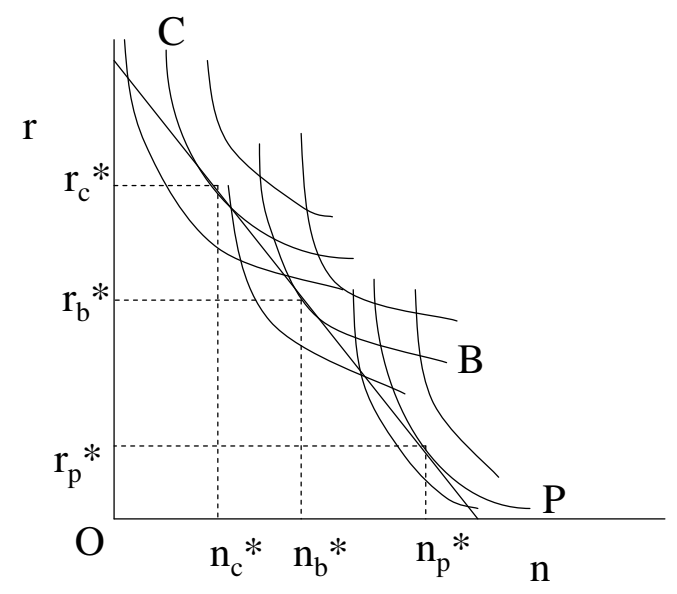

$$
\begin{aligned}
& \mathrm{n}=\text { audience size } \\
& \mathrm{r}=\text { information rate } \\
& \mathrm{C}=\text { isobenefit for contract } \\
& \mathrm{B}=\text { isobenefit for contractual boilerplate } \\
& \mathrm{P}=\text { isobenefit for property }
\end{aligned}
$$

Communication costs should be incurred as long as marginal communication cost is smaller than marginal communication benefit, but the model here emphasizes how costs should be allocated between trying to compact information (intensiveness) or reach a wide set of contexts (extensiveness). For the same cost, one can communicate at a high information rate in specialized contexts (high $r$, low $n$ ), or at a low information rate in a large set of contexts (low $r$, high $n$ ).

On the benefits side, different combinations of intensiveness and extensiveness have different values depending on one's goals. Otherwise, a single mode of legal communication with a single level of formalism would be appropriate in all instances. But this is not so. Consider first the contrast of

122. To avoid asymptotic isocost lines, the origin depicts the minimal unit of information being communicated to one person. 
contract and property. In the case of contracts, particularly those involving sophisticated parties, there are large benefits to be gained from error-free communication with one or a few parties - the parties to the contract and perhaps a third-party beneficiary. To some extent judges have to be communicated to as well. ${ }^{123}$ This is illustrated by isobenefit curve $C$ (mnemonic for contract) and those parallel to it. ${ }^{124}$ Where someone is claiming a property right, things are very different. Here one is interested in having the message travel widely, but not much information is needed in order to secure the benefits of property: a message to keep off works to protect investments against all but a few interested parties. Moreover, there are advantages to being able to transfer and compare these rights with similar ones used by other people. This is illustrated by the isobenefit curve $P$ (mnemonic for property) and those parallel to it. ${ }^{125}$

Now consider boilerplate. Like other contractual provisions, it is most useful to the contracting parties. But it deals with matters that could be walled off and dealt with in a modular way. As far as context-dependence within a contract, the benefits of high context-dependence are less than in other matters. Also, it is useful to be able to take a boilerplate term and reuse it, in which case context-dependence is not as beneficial as it might otherwise be. The isobenefit curves for boilerplate, denoted $B$ (mnemonic for boilerplate), are in between those for contract and property. Their intermediate location reflects the fact that boilerplate needs to reach an intermediately sized set of contexts (audiences, contracts, business settings). Different types of boilerplate will be located at different intermediate points and the diagram is only meant to depict its intermediate status.

We can now derive the optimal mix of intensiveness and extensiveness. In each case we want to find the mix at the point where the isocost curve is tangent to the highest isobenefit curve it can reach in each of the three situations. In the first, core contract-like case, the curve $C$ is tangent to the isocost at point $\left(n_{c}{ }^{*}, r_{c}^{*}\right)$, which means that the right will be characterized by intensive information directed at few people. In the case of curve $P$, the tangency point is at $\left(n_{p}{ }^{*}, r_{p}{ }^{*}\right)$ and the right will be characterized by less intensive but more extensive information. And in the case of boilerplate the isobenefit curve is tangent at point $\left(n_{b}{ }^{*}, r_{b}{ }^{*}\right)$, which falls between $\left(n_{c}{ }^{*}, r_{c}{ }^{*}\right)$ and $\left(n_{p}{ }^{*}, r_{p}{ }^{*}\right)$. Boilerplate is somewhere on the road from contract to property. Being part of a contract, boilerplate may not be far along this road, but

123. In contract theory, this comes under the heading of verification costs, which, despite typical assumptions of contract theory, fall on a sliding scale. See George G. Triantis, The Efficiency of Vague Contract Terms: A Response to the Schwartz-Scott Theory of U.C.C. Article 2, 62 LA. L. Rev. 1065 (2002).

124. Contracts between a few sophisticated and numerous unsophisticated parties might be somewhat closer to the curves for property than are contracts between a small number of identified and fully informed parties. For factors that make some contractual situations somewhat "intermediate" between prototypical contract and property, see Merrill \& Smith, supra note 33, at 799-809, and Smith, supra note 1, at 1151-53.

125. All the curves are concave because information rate and information extensiveness are not perfect substitutes: one has to give up more and more of one input to achieve the same amount of benefit with substitution of the other input. 
among contractual provisions boilerplate is more property-like than others in terms of the informational trade-off.

This model does allow us to derive a prediction about the relative sizes of the externality in the three situations. As I have argued elsewhere, externalities emerge on the extensive margin. ${ }^{126}$ Those doing the communicating will worry most about those they deal with, but potential audiences that are more distant-especially those not in privity with the communicator-will incur processing costs not brought home to the communicator. This is the basic reason why property, directed as it is at the widest audience, is most subject to informational externalities and is the most appropriate area for a mandatory rule like the numerus clausus that keeps the information rate down to manageable levels for remote audiences. ${ }^{127}$ But extensiveness can be extended to other aspects of the context for legal communication. Communicators will care about how a provision or other message fits into the contexts (the contract and the deal of which it is a part) at hand but will care less about other contexts. In the case of contracts this problem is small. Although it is true that there are network externalities from using standardized forms, contracts also need to be tailored to the parties' needs. ${ }^{128}$ Moreover, future dealings with the other party will make more contexts relevant to both parties.

Boilerplate is once again intermediate. If one used a more tailored provision rather than modular boilerplate, one may burden the other party, and the other party will find such a term harder to process and to accept. If so, there will be some tendency to adopt modular boilerplate in order to assure the other party. ${ }^{129}$ The more standardized boilerplate is, the more it can serve this function, but no one party may reap enough of the benefits of standardization to invest heavily in such terms. ${ }^{130}$ However, law firms will have their own boilerplate-which can serve as some assurance of not causing interactions and traps for oneself. The use of boilerplate thus lowers legal costs, in part because it is simple and in part because this simplicity through modularity allows its reuse. Although this often makes boilerplate a public good, trade associations sometimes propose boilerplate, ${ }^{131}$ and parties with particularly high stakes will sometimes have more than enough incentive to provide the optimal amount of boilerplate. ${ }^{132}$ Thus, it is an empirical question

126. Smith, supra note 1 , at 1139-48, 1153-57.

127. See Merrill \& Smith, supra note 3, at 24-42; Smith, supra note 1, at 1157-62.

128. See, e.g., Marcel Kahan \& Michael Klausner, Path Dependence in Corporate Contracting: Increasing Returns, Herd Behavior, and Cognitive Biases, 74 WASH. U. L.Q. 347 (1996); Marcel Kahan \& Michael Klausner, Standardization and Innovation in Corporate Contracting (or “The Economics of Boilerplate”), 83 VA. L. REv. 713 (1997); Michael Klausner, Corporations, Corporate Law, and Networks of Contracts, 81 VA. L. REV. 757 (1995).

129. See infra notes 136-141 and accompanying text.

130. See, e.g., sources cited supra note 128.

131. See Kevin E. Davis, The Role of Nonprofits in the Production of Boilerplate, $104 \mathrm{MiCH}$. L. REV. 1075 (2006).

132. See David D. Haddock, Why Individuals Provide Public Goods (draft November 2005) (on file with Michigan Law Review). 
whether lock-in will happen, even in the face of large changes in the context that call for some remodularization. ${ }^{133}$ While it is true that under certain assumptions about information these terms could be overreaching, the model here predicts that they will still be more modular than they would be in a world where trade associations were solely interested in putting one over on customers.

Figure 6 derives the relative sizes of the externalities, assuming that it increases with the number of contexts that are supposed to be reached. Number of contexts and externality go hand in hand. To a communicator, the costs of reaching some of these contexts will appear to be less than it is, making the isocost line as it appears to the communicator, line $L M$, less steep than the actual line $L L$, which is the "full" isocost line that reflects all the costs of the communication:

\section{Figure 6}

\section{The Divergent Communicative Trade-OfF}

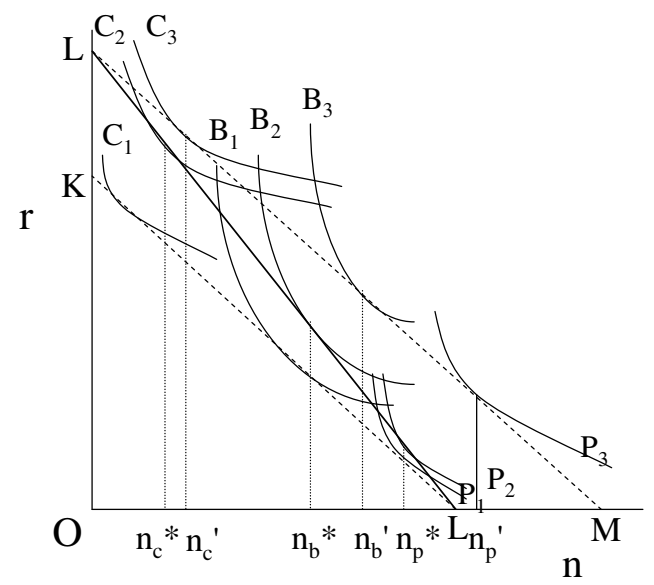

$\mathrm{n}=$ audience size

$\mathrm{r}=$ information rate

$\mathrm{C}_{1}, \mathrm{C}_{2}, \mathrm{C}_{3}=$ isobenefit curves for contract

$\mathrm{B}_{1}, \mathrm{~B}_{2}, \mathrm{~B}_{3}=$ isobenefit curves for contractual boilerplate

$\mathrm{P}_{1}, \mathrm{P}_{2}, \mathrm{P}_{3}=$ isobenefit curves for property

The communicator's choice is skewed towards excessive contextdependence, and the problem is greatest in property and least in contract. Boilerplate is in between. The externality will increase with the excess of

133. For arguments that network effects give rise to lock-in, see sources cited supra note 128 . For more cautious and skeptical views, see, for example, Mark A. Lemley \& David McGowan, Legal Implications of Network Economic Effects, 86 CAL L. Rev. 479, 562-91 (1998) (analyzing network effects in corporate and contract law and concluding that systematically suboptimal contracting has not been established, and S.J. Liebowitz \& Stephen E. Margolis, The Fable of the Keys, 33 J.L. \& ECON. 1 (1990) (arguing for rarity of strong path-dependence and questioning canonical example). 
the extensiveness chosen over the optimal level (generically, $\left.n^{\prime}-n^{*}\right)$. Consider the contractual situation. That benchmark point is at $n_{c}^{*}$ where the fullcost line $L L$ is tangent with the isobenefit curve $C_{2}$, which is the highest level of (net social) benefit attainable with this budget. Similarly for $n_{b} *$ and $n_{p}{ }^{*}$, for boilerplate and property, respectively. In each case (of contract, boilerplate, and property), the communicator will believe himself to be facing the less steep budget line. This means that the communicator will believe that he can attain a higher level of benefit than is socially optimal. ${ }^{134}$ As the degree of extensiveness called for by the situation increases, the gap between the full and apparent budget line becomes larger; more contexts means proportionally more contexts whose costs are not brought home to the communicator. In the case of contractual provisions, this externality is smaller than in the case of boilerplate which is in turn smaller than in the case of property: $n_{c}{ }^{\prime}-n_{c} *<n_{b}{ }^{\prime}-n_{b} *<n_{p}{ }^{\prime}-n_{p} *$.

If property, and to a lesser extent boilerplate, should be kept simple for these reasons, this is somewhat counterintuitive because generally with more at stake, we would expect more complexity to be worth incurring. But higher stakes can lead to efforts at greater modularization. In particular, where modularization has greater benefits, in boilerplate and even more so in property, we might expect private parties and public authorities to expend efforts on keeping things simple and standardized. Particularly if the kind of processing costs here are basic to human cognition, the fact that judges or other interpreters will themselves need to process legal communication will have a tendency to lead parties to keep things simple and for the third-party decisionmakers themselves to favor or even mandate simplicity. ${ }^{13 .}$

This model also allows a new explanation of contract "reading costs" and can be used to ground models based on such costs. The externality here is one of reading costs. Most economic models of costly contracting assume that the main cost preventing ideal, complete contracts is that information cannot be verified (to a third party) or that spelling out contingencies is simply not worth the (sometimes low) cost. ${ }^{136}$ If a contingency is remote and not too disastrous, it is not worth even incurring small drafting costs. In addition, parties who insist on going into this detail may be taken by their negotiating partners to be untrustworthy. ${ }^{137}$ In other words, from a commu-

134. There is another way to derive the externality, as discussed in Smith, supra note 1, at 1154 n.174. By selecting along line $L M$ when from a social point of view one cannot do better than $L L$, the private actor is in effect selecting along a budget line $K L$. This is the actual trade-off being made along $L M$ taking social cost into account: $K L$ shares a point with $L L$ on the $x$-axis but is parallel to line $L M$. When the private actor believes he is at point $M$, he is really at point $L$ on the $x$-axis. The actor nonideally trades off $r$ and $n$ at the rate reflected in line $L M$ (and parallel line $K L$ ), that is, at a rate of $-O L / O M$. Notice that $K L$ is tangent to the lowest drawn isoquants for contract, boilerplate, and property $\left(C_{l}, B_{l}, P_{l}\right)$, again reflecting lower social benefits than in the case of $C_{2}, B_{2}$, and $P_{2}$.

135. Smith, supra note 1, at 1155-60.

136. See, e.g., Eggleston et al., supra note 4, at 91-126; Jean Tirole, Incomplete Contracts: Where Do We Stand?, 67 Econometrica 741 (1999).

137. See, e.g., Eggleston et al., supra note 4, at 117-19. 
nicative point of view, the emphasis has been on contracting costs from the supply side - those faced by the communicator.

One exception to this supply-side approach is Eric Rasmusen's model of contracting based on reading costs. ${ }^{138}$ On this model, if two parties are contracting, the nondrafting party (of any given provision) must read the contract, but finding potential traps is costly and will be more costly the longer the contract is. For Rasmusen, length is a proxy for complexity because on his model, "a complex contract is a contract with one extra clause added. ${ }^{, 139}$ For the drafter, assuring the other party that there are no traps is also costly. Knowing this, the party drafting will draft a shorter (incomplete) contract in order to give this assurance at lower cost. By using a short contract, the reading party can enter into the contract without worrying about traps or spending a lot of time and effort checking to make sure that they are not there.

One potential objection to this theory is that one may doubt that reading costs are so high. Why should long contracts be so costly to read? A few extra pages can be read fairly quickly and lawyers are experts at looking for provisions that do not suit their clients, especially if the problem is the addition or not of a given clause. At least as between sophisticated parties, contract length seems hard to derive from the costs of reading.

Once we move away from identifying complexity with length, reading costs are easier to understand as an obstacle to complete contracting. Complex contracts, those containing many parts with relatively many interactions, are difficult to process. Modularizing the contract can help but may require omitting some interactions that would tailor the contract to distinguish between situations. For example, one could imagine a choice of law provision making reference to different problems that could arise under other provisions of the contract and prescribing a different choice depending on which provision is in question (which might carry with it some advantages where the contract is supposed to be performed in multiple locations). If, to avoid complexity from such interaction, a single jurisdiction's law is selected, incompleteness is chosen to manage complexity. This may typically result in a shorter boilerplate provision, but not necessarily. ${ }^{140}$

The costs of reading can help explain the modularity of contacts, but the information-cost theory here allows us to be more specific about the nature of reading costs. It is well-known among practitioners dealing with contracts that boilerplate can be readily identified and mentally segregated, which is possible because of its relatively stereotyped interaction with the operative

138. Eric Bennett Rasmusen, Explaining Incomplete Contracts as the Result of ContractReading Costs, Advances Econ. Analysis \& Pol'y, 2001, available at http://www.bepress.com/ bejeap/advances/vol1/iss1/art2/index.html (follow "View the Article" hyperlink).

139. Id. at $* 31$.

140. It is true that one information-theoretic approach to complexity is to measure it by the length of the shortest description in an agreed-upon language. The language and style that contracts are written in give no assurance of satisfying the conditions for applying this algorithmic or descriptional complexity (also known as Kolmogorov complexity). Ming Li \& PAUL VitánYI, AN INTRODUCTION to Kolmogorov CoMPLEXITY AND ITS APPLICATIONS (2d ed. 1997). 
provisions of the contract. ${ }^{141}$ More generally, modularity is a method of dealing with complexity - the type of complexity faced by one reading a contract. Modularity can be regarded as making contracts simpler; with fewer potential interactions to trace out, it is easier to convince a negotiating party that there are no traps. Interactions make contracts more complex and potentially harbor traps. Thus, a model like Rasmusen's should predict that contracts should be more modular, but not necessarily shorter, than they would in a hypothetical world of zero reading costs.

\section{FurTher APPLICATIONS}

The advantages of modularity help explain some major features of boilerplate and their function. Boilerplate is more encapsulated and tends to avoid interaction with substantive terms of the contract. This makes boilerplate more portable and revisable, and makes assurance to the nondrafting party easier to furnish. In these ways, boilerplate reduces reading costs, a type of processing cost. The very notion of reading costs can be linked up to well-known limits on human cognition, limits that find their expression in other human artifacts, from computer programs to business organizations. In this Part, I will provide further, indirect evidence of the importance of modularity in boilerplate and in the process of contracting more generally.

\section{A. Nonmodularity in Legal Realism}

The legal realists were antiformalists, and I have already had occasion to mention their advocacy of context-dependence-the opposite of formalism-in the interpretation of contacts. ${ }^{142}$ Realists have been especially harsh in their attacks on the four-corners rule, under which an integrated agreement is to be interpreted without extrinsic evidence, and the parol evidence rule, under which parol evidence is inadmissible unless a contract is ambiguous. ${ }^{143}$ From the early-twentieth century, contract doctrine to some extent trended away from formalism and towards an increasing openness to evidence of the contractual setting. ${ }^{144}$ More recently, courts and commentary

141. Scott Burnham advises reading a contract in several passes, the second of which involves identifying the boilerplate declarations and focusing on the rights and duties of the parties, especially how they are conditioned on the happening of some event. On the theory presented here this makes sense: identifying and mentally segregating boilerplate occurs at the same stage that one starts worrying about interdependencies. Scott J. Burnham, How To Read a Contract, 45 ARIz. L. Rev. 133, 138, 144-45, 147 (2003).

142. See supra notes $56-57$ and accompanying text.

143. See Smith, supra note 1, at 1177-90.

144. See Smith, supra note 1, at 1182-83. A turning point in this history of the parol evidence rule is Pacific Gas \& Electric Co. v. G.W. Thomas Drayage \& Rigging Co., 442 P.2d 641 (Cal. 1968), in which the California Supreme Court allowed extrinsic evidence to be introduced on the question of whether a contract was ambiguous. In typical realist fashion, Chief Justice Traynor asserted that adherence to the traditional parol evidence rule would reflect "a judicial belief in the possibility of perfect verbal expression. ... [a] belief [that] is a remnant of a primitive faith in the inherent potency and inherent meaning of words." Id. at 643-44 (citation and footnote omitted). 
have pulled back somewhat from the more contextualized approach that was the trend in the 1960s and 1970s. ${ }^{145}$ Whether this partial retrenchment reflects in part the complexity of the task that relatively nonmodular approaches to contract law placed on courts is beyond the scope of this Article, but it is suggestive. Perhaps more telling is that the realists themselves had difficulty maintaining their context-sensitive approach in one area over which they had more direct control (and suffered the consequences of nonmodularity) - the writing of contracts casebooks.

Contracts was one of the areas that realists saw as most in need of a move away from the (to them) illusory autonomous concepts like offer and agreement, and towards greater sensitivity to commercial, political, and social context. For example, Arthur Corbin begins his treatise with an argument that an open-textured term like "reasonable" calls for contextualized decisionmaking:

It must not be supposed that contract problems have been solved by the dictum that expectations must be "reasonable." Reasonableness is no more absolute in character than is justice or morality. Like them it is an expression of the customs and mores of men-the customs and mores that are themselves complex, variable with time and place, inconsistent and contradictory. Nevertheless, the term is useful, giving direction to judicial research, and producing workable results. The reasonably prudent man, reasonable care and diligence, reasonable expectations, are terms that are not to be abandoned, at least until we can demonstrate that others will work better. $^{146}$

Felix Cohen, too, took the question "Is there a contract?" as the vehicle to attack traditional legal analysis for being insufficiently empirically oriented and not pragmatic enough, using anti-metaphysical and pragmatist rhetoric typical of the philosophy of the day. ${ }^{147}$ Realist lawyers are engaged in the positive task of predicting what judges will do, and realist judges are asked to decide based on social reality what the law should be. The charge against the conceptualists that they engaged in mystical thinking was a common one and carried over to their attitude toward language itself. Carrying forward this rationalist, realist hostility, Frederick Philbrick made a patronizing attack on belief in the determinacy of language:

145. Gary J. Aichele, Legal Realism and Twentieth-Century American JurispruDENCE, at x (1990) ("Impossible only a decade ago, 'mechanical jurisprudence' has made a remarkable comeback, and a new legal formalism may yet triumph as the principal mode of [judiciall interpretation ....."); David Charny, The New Formalism in Contract, 66 U. CHI. L. Rev. 842 (1999); Ralph James Mooney, The New Conceptualism in Contract Law, 74 Or. L. Rev. 1131 (1995); G. Richard Shell, Contracts in the Modern Supreme Court, 81 CAL. L. Rev. 431, 436 (1993); Peter Nash Swisher, A Realistic Consensus Approach to the Insurance Law Doctrine of Reasonable Expectations, 35 TORT \& INs. L.J. 729 (2000). On textualism versus contextualism, see Goetz \& Scott, supra note 83.

146. Arthur Linton Corbin, Corbin on Contracts $\S 1$, at 2 (1 vol. ed. 1952).

147. Felix S. Cohen, Transcendental Nonsense and the Functional Approach, 35 Colum. L. Rev. 809, 839-42 (1935). 
First we had better dispose of some superstitions. A primitive notion survives in many parts of the world-it is perhaps hardly rational enough to be called a belief - that the connection between a word and the thing it stands for is closer than the merely mental connection between symbol and object. Most primitive peoples imagine that the word not only stands for but in some sense $i s$ the thing. ${ }^{148}$

The critique of the determinacy of language was central to the realists' call for contextualized decisionmaking. ${ }^{149}$

Interestingly, the realist who was least unsympathetic to the use of legal concepts, Karl Lllewellyn, took the appearance of boilerplate as a reason to enforce contracts according to contextualized expectation and not the language itself:

Instead of thinking about "assent" to boiler-plate clauses, we can recognize that so far as concerns the specific, there is no assent at all. What has in fact been assented to, specifically, are the few dickered terms, and the broad type of the transaction, and but one thing more. . . . a blanket assent (not a specific assent) to any not unreasonable or indecent terms the seller may have on his form, which do not alter or eviscerate the reasonable meaning of the dickered terms. ${ }^{150}$

The need for modularity suggests the strengths and limits of this argument. In the consumer context, forcing drafters to be very clear if they want to override usual buyer expectations allows buyers to approach contracts as if they are modular. There is less need for the buyer to parse the language and look for interactions between the boilerplate term and the rest of the contract and the business context. However, where sufficient notice is given or where both parties are sophisticated enough, the use of boilerplate can harness the benefits of modularity by being interpreted without great attention to context-not only course of dealing and industry custom, but also the

148. Frederick A. Philbrick, Language and the Law: The Semantics of Forensic ENGLISH 27 (1949).

149. See also Lon L. Fuller, Positivism and Fidelity to Law-A Reply to Professor Hart, 71 HARV. L. REV. 630, 663 (1958) (arguing against Hart's attempt to preserve a core of meaning in legal terms and contending that all interpretation of even the seemingly plainest words requires an inquiry into purpose). See generally Smith, supra note 1, at 1177-82 (discussing realism and formalism in contract interpretation). James Bradley Thayer, even prior to realism, made much the same kind of argument, when he scoffed at the "lawyer's Paradise where all words have a fixed, precisely ascertained meaning" and argued that "the fatal necessity of looking outside the text in order to identify persons and things, tends steadily to destroy such illusions and to reveal the essential imperfection of language, whether written or spoken.” JAMES BRADLEY THAYER, A Preliminary Treatise on Evidence at the Common Law 428-29 (1898). One exception to this dismissive attitude towards concepts was Karl Llewellyn, who did not reject conceptual analysis or broad analytical categories, but rejected its use at the level of rule application, especially if it meant asking courts to answer unanswerable questions. Alan Schwartz, Karl Llewellyn and the Origins of Contract Theory, in THE JURISPRUdential Foundations of CORPORATE AND Commercial Law 12, 17 \& n.34, 22, 41 (Jody S. Kraus \& Steven D. Walt eds., 2000); see also Jeanne L. Schroeder, Death and Transfiguration: The Myth That the U.C.C. Killed "Property", 69 Temp. L. Rev. 1281 (1996) (arguing that Llewellyn did not discard property concepts when eliminating older title analysis).

150. Karl N. Llewellyn, The Common Law Tradition: Deciding Appeals 370 (1960). 
rest of the contract itself. Llewellyn's approach to boilerplate, like that of the other realists, is ironically too one-size-fits-all in its preference for context over modularity.

In this approach to contracts, the realists were pursuing a vision closely related to their bundle-of-rights picture of property. In the bundle of rights, the realists stressed the social purposes of property and thus emphasized the relations holding between people and took the focus off property as an in rem right to a thing. The realists favored breaking property rights down into ever smaller constituent parts (sticks) and redistributing the sticks in accord with policy goals. ${ }^{151}$ In general, the realists systematically ignored information costs. So as long as there was any benefit from tailoring or reliance on context, only a lack of enlightenment would seem (to them) to stand in the way of openness to these context-dependent approaches. Because they saw little to recommend formalism, the realists were willing to throw out the advantages of invariance to context.

The realist revolution was never quite complete in the courts and the tide has reversed somewhat (and more so in the commentary). But there is one arena in which the realists had to live with the consequences of their embrace of context and disregard for modularity: their efforts to implement their project through writing casebooks on contracts. The goal among realists was to make the study of contracts more responsive to commercial and social realities. The more thoroughgoing realist approach went as far as to organize contracts casebooks by the subject matter of contracts. For an extreme example, Harold Havighurst's contracts book proudly announces that its "[c] ases are grouped according to subject matter and not according to the doctrines employed," 152 and that this will mean that "[t]he part that relationship, circumstance, and custom play in molding the bargain becomes more readily apparent." ${ }^{, 153}$ The aim is to bring out contextual connections and to avoid conceptualism, both of which push in the direction of lessened modularity. ${ }^{154}$ True to its word, the book is divided into parts for "Services," "Gratuities," "Loans," and "Contracts for the Sale of Goods.,"155 The part on

151. See Merrill \& Smith, supra note 8, at 357-60, 365-66; see also J.E. Penner, The "Bundle of Rights" Picture of Property, 43 UCLA L. Rev. 711, 802-03 (1996). For some realist pronouncements to this effect, see, for example, Arthur Linton Corbin, Taxation of Seats on the Stock Exchange, 31 YALE L.J. 429, 429 (1922), which argues: "Our concept of property has shifted ... '[P]roperty' has ceased to describe any res, or object of sense, at all, and has become merely a bundle of legal relations-rights, powers, privileges, immunities." See also Max Radin, A Restatement of Hohfeld, 51 Harv. L. Rev. 1141 (1938) (interpreting the Hohfeldian scheme from a legal realist's point of view). For a more recent version, see Thomas C. Grey, The Disintegration of Property, in NOMOS XXII 69 (J. Roland Pennock \& John W. Chapman eds., 1980).

152. A Selection of Contract Cases and Related Quasi-Contract Cases, at iii (Harold C. Havighurst ed., 1934) [hereinafter Havighurst].

153. Id

154. What the realists wound up doing is not totally nonmodular. Even in bringing in context, they did organize by contract subject area. Nevertheless, these groupings of subject matter probably were not meant to have the kind of freestanding quality that units in a more traditional casebook would have.

155. Havighurst, supra note 152, at vii-viii. 
Services is divided into chapters for "Regular Employment," sion Agents," "Real Estate Brokers," "Physicians," "Services in the Home, Care of Sick and Aged," "Rescues, Recovery of Property, Apprehension of Criminals," and "Building and Construction."157 And so on (and on). Another professedly idiosyncratic book, characteristically entitled Contract in Context, organized the course around a building dispute, with no traditional headings. ${ }^{158}$ The only major current casebook with echoes of this realist tradition is Stewart Macaulay et al.'s Contracts: Law in Action, which mixes headings such as "Protecting the Expectation Interest," "Contract in a Family Setting," "An Introduction to the Law of Consideration," "Contracts to Provide for the Old: Contract and Restitution as a Substitute for an Extended Family," "Franchise and Employment Relations," and "Social Control and the Interests of Others." 159 The book partially organizes on the basis of subject matter and emphasizes context over general principles. This approach does have an organization but foregoes the strong modularity of the traditional approach based on principles and doctrines. In an effort to battle conceptualism, none of the organizational benefits of concepts can be employed. At any given point, any piece of material is potentially related to any other. It is difficult on this hyperrealist approach to hive off some material and treat it in even a semiautonomous fashion. It is a relatively nonmodular approach.

This realist approach never quite caught on, and I suggest that the reason was its disregard for the principle of modularity. Indeed, current casebooks look a lot more like the traditional books Havighurst and other ardent realists were trying to supplant. Even Havighurst had to compromise in the direction of modularity by including little capsule explanations. For example, in the Employment chapter, the Second Edition adds capsules on "Unilateral and Bilateral Contracts," "Objective and Subjective Tests of Contract Formation," the "Statute of Frauds," "Quantum Meruit," "Designation of Parties," "Statutory Provisions," "Special Interrogatories," "Consideration," and so on. ${ }^{160}$

Because fewer of the benefits of modularity were available on the subject-matter based approach, many authors did not go this far. Even the

156. This is further divided into sections on "Compensation, Wages, Bonuses," "Quality of Work, Conduct of Employee," "Abandonment of Service, Sickness, Death, Changes in Employer's Business, Duration of the Employment," "Remedies of Employee," and "Remedies of Employer." Id. at vii.

157. The chapter on Building and Construction is further divided into sections on "The Contract Price, Extras, Cost Plus Contracts," "Defective Construction, Departure from Specifications," "Delays in Construction and in Payment, Termination and Abandonment," "Destruction of Work Pending Performance," and "Assignees, Sub-contractors, Laborers, Materialmen, and Surety." Id.

158. Addison Mueller, Contract in Context (1951). The author had set out his views on contracts casebooks in Addison Mueller, There Is Madness in Our Methods, 3 J. Legal Educ. 93 (1950).

159. Stewart Macaulay, John Kidwell \& William Whitford, 1 Contracts: LaW in Action, at vii-xiii (2d ed. 2003).

160. Harold C. Havighurst, Cases and Materials on the law of Contracts 5-198 (2d ed. 1950). 
radical realist casebooks had to compromise with conceptualism in later editions. The failed experiment of organizing contracts casebooks by subject matter is a testament to the perils of ignoring the advantages of modularity.

\section{B. Comparative Contracts and the Seams in the Web of Law}

If the theory based on modularity is correct, then contractual boilerplate is in principle not the only way to achieve the benefits of modularity. At various points I have mentioned the hostility of many legal realists to conceptualism and formalism alike. In this Section, I give a preliminary sketch of the role that concepts play in a modular theory of law. In civil law, modularity is achieved through defining these concepts and providing off-the-rack solutions in the civil code. Finally, I turn to how differential formalism qualifies the notion that law is a seamless web.

At one level, concepts and formalism under our definition do go hand in hand. The whole point of a concept in traditional conceptualism is its relative abstractness and autonomy from the messy details of the factual context (for example, business dealings in a particular industry). In other words, conceptualism is one way (and not the only way) of reducing contextdependence. Again, because formalism and its reverse, context-dependence, are matters of degree, one can err in the direction of too much contextdependence or too little. And one must ask which actors-private parties, judges, legislators, and administrators-are likely to come close to choosing whatever the optimal level of context-dependence might be. One assurance for getting to the neighborhood of the optimal point is that all of these actors, more or less, face processing costs, and so will have some tendency to look favorably upon modular and formal solutions when interdependencies present difficulties. The problem comes when decisions by any of these actors have implications for contexts which that actor does not directly face.

One major difference between common and civil law, and German law in particular, is that German law, unlike the common law, spells out concepts very systematically in legislation. ${ }^{161}$ Conceptualism (Begriffsjurisprudenz) was particularly popular during the formative period of the German Civil Code of 1896 (Bürgerliches Gesetzbuch), which was a product of the latenineteenth century, ${ }^{162}$ and despite more recent approaches that downplay the role of concepts, conceptualism is more pronounced in German law

161. See generally John Henry Merryman, The Civil Law Tradition: An Introduction to the Legal Systems of Western Europe and Latin America (2d ed. 1985); Alan Watson, The Making of the Civil Law 168 (1981). On German law, see, for example, Otto Palandt, Bürgerliches Gesetzbuch (Peter Bassenge et al. eds., 58th ed. 1999), and Introduction to German LaW (Werner F. Ebke \& Matthew W. Finkin eds., 1996).

162. It came into force on January 1, 1900. See Konrad Zweigert \& Hein Kötz, Introduction to Comparative LaW 143-44 (Tony Weir trans., Clarendon Press 3d rev. ed. 1998) (1977) (Professor Gustav Radbruch, who went on to become the Minister of Justice of the Weimar Republic, opined that the German Civil Code of 1896 was "more 'the cadence of the nineteenth than the upbeat to the twentieth century....'”); see also Carl Baudenbacher, Some Remarks on the Method of Civil Law, 34 Tex. InT'L L.J. 333, 340 (1999). 
than in U.S. law. ${ }^{163}$ As a result, individual contracts do not have to devote much effort to defining these concepts. Some of what a U.S. contract would accomplish by means of boilerplate provisions is simply in the background civil law in Germany. Claire Hill and Christopher King cite this feature of German law along with a more homogeneous legal and business culture as reasons why German contracts tend to be shorter than their U.S. counterparts. ${ }^{164}$

We can hypothesize here that German contracts are modular as well as short. The structure of the civil law itself provides for a high degree of modularity. To the extent that use of the system is quasi-mandatory, the law in Germany pushes parties to a highly modular style of contracting, but through off-the-rack law rather than through privately created boilerplate. German law allows modules, especially those involving definitions, to be omitted from contracts themselves. Both boilerplate provisions and the offthe-rack provisions of German law achieve modularity, but in very different ways. It may also be the case that German law, along with an institutional structure in which "notaries" vouch for the enforceability of contracts, promotes a greater degree of modularity than U.S. law. ${ }^{165}$ Given that the contracting context at least until recently has been quite different in Germany, it is beyond the scope of this Article whether a possibly greater degree of modularity heavily promoted by the legal system is an advantage or not.

One of the functions of defining concepts is to help differentiate various areas of the law from each other. Thus, if property involves exclusion and in rem nature, this helps define the scope of property vis-à-vis contract. This type of differentiation is ingrained in the civil law tradition but has fallen out of favor in common law jurisdictions, especially in the United States. More recently, some English philosophers of law, especially those taking up Joseph Raz's problem of "individuating" laws, have pursued the question of defining branches of the law philosophically. ${ }^{166}$ I suggest that the benefits of doing this are closely tied to the role of modularity in managing complexity.

Recognizing this role of modularity calls into question the oftenrepeated metaphor that law is a "seamless web." This is a well-worn cliché, partly because it potentially appeals to those of very different views on conceptualism and formalism. ${ }^{167}$ To traditional conceptualists and formalists, the

163. See, e.g., Baudenbacher, supra note 162, at 336-37.

164. Claire A. Hill \& Christopher King, How Do German Contracts Do as Much with Fewer Words?, 79 CHI.-Kent L. REV. 889 (2004).

165. Beurkundungsgesetz [Notarial Authentication Act], Aug. 28, 1969 BGB1. I at 1513, $\S \S 17-21$ (F.R.G.).

166. Penner, supra note 33, at 32-68; Joseph Raz, The Concept of a Legal System 7092, 140-47 (2d ed. 1980).

167. Frederic William Maitland, A Prologue to a History of English Law, 14 LAw Q. REv. 13, 13 (1898) ("Such is the unity of all history that any one who endeavours to tell a piece of it must feel that his first sentence tears a seamless web."); see also Frederick Pollock \& Frederic WILliam Maitland, The History of English LaW 1 (2d ed. 1899); Ethan Katsh, Law in a Digital World: Computer Networks and Cyberspace, 38 VILL. L. REV. 403, 403-04 (1993) ("This metaphor 
phrase is cautionary in that a change may have unanticipated consequences. realists, who are skeptical about the neatness and coherence implied by the traditional invocations of the "seamless web" metaphor, make a case for a different sort of seamlessness themselves: a need to look beyond narrow doctrine for sensible solutions that take into account how law in general can solve social problems. ${ }^{168}$ To the realists, law is not even autonomous, but rather seamlessly connected to social context.

That law has internal and external connections of this sort is hard to deny. But in the case of formalism versus contextualism, the seamlessness of law is a matter of degree. Maximum seamlessness implies no benefit to modularity. Regardless of whether they explicitly thought of their task this way, the conceptualists and traditional treatise writers divided law into subject areas (and subareas) and distinguished concepts. By differentiating areas of law and defining-and limiting - the connections between them and between law and its context, the designers of a legal system can achieve some of the benefits of modularity in managing complexity. These include greater ease of use and more adaptability to certain kinds of change in the external environment that call for change in the law itself. Given the central role modularity plays in many facets of human existence and its connection to limits on human cognition, it would be quite surprising if law called for a corner solution of seamlessness.

\section{CONCLUSION}

The modularity of boilerplate is but one aspect of a much larger phenomenon that is pervasive throughout law and the rest of human creation of artifacts. Ultimately, modularity reflects the limits of human cognition. Modularity is a much more promising place to look for the effects of those

suggests that law not only has an intricate structure, but also that all parts of the law fit together smoothly, that each part is linked to every other part and that the whole arrangement grows and evolves according to plan.").

168. See supra note 57 and accompanying text. Before arguing that legal norms block consideration of some kinds of information, thus in this Article's terms increasing modularity, Frederick Schauer summarizes the modern view of seamlessness:

The law is a seamless web, so the old saw goes, but so too is life. Just as the categories and concepts of law are pervasively interconnected, the categories with which we divide up the world are similarly conjoined. The demarcations that people use to organize their perceptions and their lives are not rigid and mutually exclusive, but rather constitute a set of overlapping and fuzzy-edged constructs, linked in such a way that changes in the pressure applied at any one point in society are likely to reverberate throughout much of the network that is our existence.

What makes these interrelationships important to lawyers is that law itself is undeniably part of a larger whole. The seamless web of law is one component of the seamless web of life. And if the seamless web metaphor is indeed as apt for life as it is for law, then changes in any part of our social existence and organization are likely to be reflected not only in the content but also in the very nature of law.

Frederick Schauer, Lawyers and Lawmaking, 83 Mich. L. Rev. 1141, 1141 (1985) (reviewing Bruce A. Ackerman, Reconstructing American LaW (1984)). 
limits than in many of the deviations from rationality that have received the most attention in recent years. ${ }^{169}$

One of the most striking implications of the theory and the hypotheses offered about boilerplate, contract, and property in this paper is that they suggest benefits of formalism that have been overlooked by the realists and formalists and their successors alike. Boilerplate is best interpreted in a less holistic, context-dependent manner than are contracts more generally. This differential formalism suggests that images of the law popular with all these types of people are quite misleading. The image of the law as a "seamless web" is appealing and has some truth in it, but it misses an important part of the picture. What is deeply woven into the structure of the law is the modularity that human minds require in order to make legal artifacts useful. Exploiting the benefits of information hiding and portability can be seen as consequences of bounded rationality. ${ }^{170}$ Modularity and other formal devices are more important in some areas, like contracts, than in others, like property, precisely because these purposes differ from one area to the next. And boilerplate is interesting and revealing because it is perched somewhere between the poles of contract and property.

169. See, e.g., Behavioral LaW and Economics (Cass R. Sunstein ed., 2000); Russell B. Korobkin \& Thomas S. Ulen, Law and Behavioral Science: Removing the Rationality Assumption from Law and Economics, 88 CAL. L. REv. 1051 (2000).

170. This was Herbert Simon's view, even though he regarded the mind as a general cognition device and did not emphasize the modularity of mind itself. See Simon, supra note 13. Modularity of artifacts like computer programs, organizations, and law itself can be important to human information processors even if the mind itself is not as modular as most cognitive scientists now accept. 